Article

\title{
Novel N-Substituted Amino Acid Hydrazone-Isatin Derivatives: Synthesis, Antioxidant Activity, and Anticancer Activity in 2D and 3D Models In Vitro
}

\author{
Ingrida Tumosienè ${ }^{1}$, Ilona Jonuškienè ${ }^{1} \mathbb{D}$, Kristina Kantminienè ${ }^{2, * \mathbb{D}}$, Vytautas Mickevičius ${ }^{1}$ and \\ Vilma Petrikaite $\dot{3}^{3,4,5}$
}

1 Department of Organic Chemistry, Kaunas University of Technology, Radvilènu pl. 19, LT-50254 Kaunas, Lithuania; ingrida.tumosiene@ktu.lt (I.T.); ilona.jonuskiene@ktu.lt (I.J.); vytautas.mickevicius@ktu.lt (V.M.)

2 Department of Physical and Inorganic Chemistry, Kaunas University of Technology, Radvilènu pl. 19, LT-50254 Kaunas, Lithuania

3 Laboratory of Drug Targets Histopathology, Institute of Cardiology, Lithuanian University of Health Sciences, Sukilèliu pr. 13, LT-50162 Kaunas, Lithuania; vilma.petrikaite@lsmuni.lt

4 Institute of Physiology and Pharmacology, Faculty of Medicine, Lithuanian University of Health Sciences, A. Mickevičiaus g. 9, LT-44307 Kaunas, Lithuania

5 Life Sciences Center, Institute of Biotechnology, Vilnius University, Saulètekio al. 7, LT-10257 Vilnius, Lithuania

* Correspondence: kristina.kantminiene@ktu.lt

check for updates

Citation: Tumosienè, I.; Jonuškienè, I.; Kantminienè, K.; Mickevičius, V.; Petrikaitè, V. Novel N-Substituted Amino Acid Hydrazone-Isatin Derivatives: Synthesis, Antioxidant Activity, and Anticancer Activity in 2D and 3D Models In Vitro. Int. J. Mol. Sci. 2021, 22, 7799. https://doi.org/ $10.3390 /$ ijms22157799

Academic Editor: Silvie Rimpelova

Received: 18 June 2021

Accepted: 19 July 2021

Published: 21 July 2021

Publisher's Note: MDPI stays neutral with regard to jurisdictional claims in published maps and institutional affiliations.

Copyright: (c) 2021 by the authors. Licensee MDPI, Basel, Switzerland. This article is an open access article distributed under the terms and conditions of the Creative Commons Attribution (CC BY) license (https:// creativecommons.org/licenses/by/ $4.0 /)$.

\begin{abstract}
A series of novel mono and bishydrazones each bearing a 2-oxindole moiety along with substituted phenylaminopropanamide, pyrrolidin-2-one, benzimidazole, diphenylmethane, or diphenylamine fragments were synthesized, and their anticancer activities were tested by MTT assay against human melanoma A375 and colon adenocarcinoma HT-29 cell lines. In general, the synthesized compounds were more cytotoxic against HT-29 than A375. 3-((4-Methoxyphenyl)(3-oxo-3-(2-(2oxoindolin-3-ylidene)hydrazinyl)propyl)amino)- $N^{\prime}$-(2-oxoindolin-3-ylidene)propanehydrazide and $\left(N^{\prime}, N^{\prime \prime \prime}\right)$-1, $1^{\prime}$-(methylenebis(4,1-phenylene))bis(5-oxo- $N^{\prime}$-(2-oxoindolin-3-ylidene)pyrrolidine-3-carbo hydrazide) were identified as the most active compounds against HT-29 in 2D and 3D cell cultures. The same compounds showed the highest antioxidant activity among the synthesized compounds screened by ferric reducing antioxidant power assay (FRAP). Their antioxidant activity is on par with that of a well-known antioxidant ascorbic acid.
\end{abstract}

Keywords: hydrazone; isatin; 2-oxindole; pyrrolidin-2-one; colon cancer; melanoma; 3D tumor model; clonogenic

\section{Introduction}

Cancer is a malignant disease characterized by rapid and uncontrolled cell proliferation [1]. The early cancer treatment strategies were based on non-specific chemotherapeutic agents that block DNA synthesis in replicating cells [2], act as antimetabolites [3], or induce cell cycle arrest by other mechanisms [4]. Almost all existing anticancer cytostatic drugs have severe side effects due to low selectivity of the antiproliferative action and allow tumors to develop resistance to multiple chemotherapeutic drugs. The search for new effective anticancer agents with superior selectivity towards cancer cells is still of crucial importance [5]. The more recent strategies based on the targeted therapies aim at the identification and targeting of biomarkers specific for cancer cells, such as deregulated, mutated, or overexpressed proteins [6]. Protein kinases constitute important molecular targets for the development of novel anticancer agents, and a number of kinase inhibitors have been developed. Some are already in clinical use [7-9].

Isatin ( $1 H$-indole-2,3-dione) is a versatile heterocyclic compound which has been attracting the attention of medicinal chemists worldwide as a synthetic building block due to the 
various biological activities of its derivatives. Among the latter, compounds bearing an oxindole scaffold constitute a group of promising compounds endowed with significant biological activities, such as anticonvulsant, antimicrobial, antitubercular [10], antileishmanial [11], anti-HIV [12], antioxidative [13], antiproliferative [14], and anticancer [15,16] activities.

Oxindole derivatives have been widely recognized in cancer therapeutics as multikinase inhibitors. The progress towards synthetic oxindole derivatives accelerated with the FDA approval of sunitinib for the treatment of metastatic renal cell cancer [17], which acts as an inhibitor of several tyrosine kinases at nanomolar concentrations [18]. Optimization of the substituents around the oxindole nucleus led to the development of several other oxindole-based kinase inhibitors, including toceranib, the only dog-specific anti-cancer drug [19], and nintedanib, which has been approved for use in the United States to treat idiopathic pulmonary fibrosis with a progressive phenotype [20].

Kinase inhibitors semaxanib and orantinib bear an oxindole moiety with a substituent at the C3 position [21]. Semaxanib has reached phase III clinical trials in the treatment of advanced colorectal cancer [22]; and orantinib is in phase II clinical trials for the treatment of breast cancer and in phase III clinical trials for the treatment of hepatocellular carcinoma [23].

Wang et al. have reported syntheses of isatin derivatives bearing an $\alpha, \beta$-unsaturated ketone moiety as the only substituent of an oxindole moiety at $\mathrm{C} 3$, and they have promising anticancer properties which are dependent on the electron-donating substituents on the benzyl ring [24].

Hydrazone derivatives, whose biological activity is associated with the presence of the active azomethine pharmacophore, constitute another significant class of biologically active compounds in medicinal and pharmaceutical chemistry [25]. These compounds, in combination with various heterocyclic scaffolds, produce diverse biological results, including antioxidant and anticancer activities [26-28].

3-((2,6-Dichlorobenzylidene)hydrazono)indolin-2-one and 3-((2-chloro-6-fluoroben zylidene)hydrazono)indolin-2-one showed excellent activity against human breast adenocarcinoma cell line MCF7 using the MTT assay, whereas 3-((2-bromobenzylidene)hydrazono) indolin-2-one showed cytotoxicity against MCF7 and human ovarian adenocarcinoma (A2780) [29].

A hydrazone moiety has been used as a linker in the construction of bis-isatin compounds with vast structural variety and numerous biological activities [15]. Ibrahim et al. have reported syntheses of variously substituted bis(2-oxoindolin-3-ylidene)- $1 H$-pyrrole2,4-dicarbohydrazide derivatives, which have shown promising anticancer activity against HepG2 (liver), MCF-7 (breast), and HCT-116 (colon) human cancer cell lines [30].

5-Oxopyrrolidine is yet another scaffold incorporated in natural and synthetic biologically active compounds. The 2-pyrrolidinone rich fraction of Brassica oleracea var. capitatahas has been shown to exhibit antioxidant and in vitro anticancer activities [31]. Recently, the antifungal and anticancer properties exhibited by several compounds embedded with pyrrolidine-hydrazone and pyrrolidine-oxindole moieties have been reported [32,33].

As a continuation of our interest in further searching for the nitrogen-containing heterocyclic compounds possessing anticancer and antioxidant activities [34-36], we report herein the syntheses of a series of derivatives bearing one or two 2-oxindole-hydrazone moieties, and evaluations of their anticancer and antioxidant activities. Two human cell lines of different origins, namely, malignant melanoma (A375) and human colon adenocarcinoma (HT-29), were selected to test the proliferation inhibition and colonyforming inhibition of the synthesized compounds. Both cell lines are considered to be derived from very aggressive types of tumors, and resistance develops quite often during treatment with drugs $[37,38]$. In order to combat this resistance, combinations of drugs with different mechanisms of action are used. Kinase inhibitors such as dabrafenib [39] and dasatinib are often used [40]. Many more compounds are being studied at different stages of preclinical research. We decided to also explore the activity of novel compounds in tumor spheroids (3D cultures) - as they mimic the real tumor microenvironment much better than 
cell monolayers [41]—and identify the most promising hydrazone-isatin derivatives for further development.

\section{Results and Discussion}

\subsection{Chemistry}

Target hydrazones 12-17 were synthesized in reactions of the corresponding hydrazides 1-6, each time with a slight excess (molar ratio 1:1.2) of isatin in methanol, in the presence of glacial acetic acid, at $65^{\circ} \mathrm{C}$, giving $58-96 \%$ yields (Scheme 1 ).

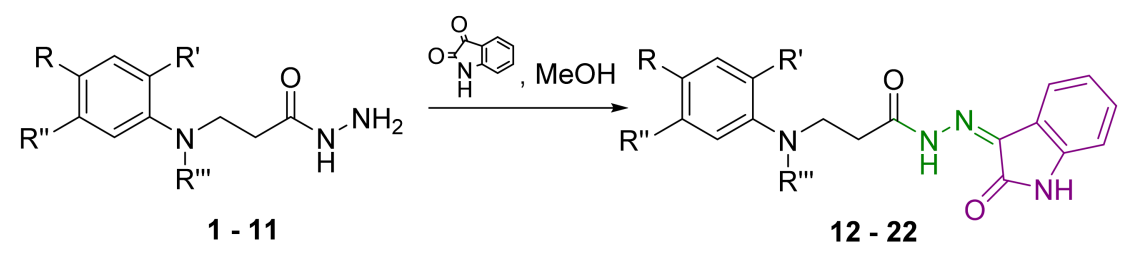

\begin{tabular}{|c|c|c|c|c|}
\hline No & $\mathbf{R}$ & $\mathbf{R}^{\prime}$ & R' & R'” \\
\hline 12 & $\mathrm{H}$ & $\mathrm{H}$ & $\mathrm{H}$ & $\mathrm{H}$ \\
\hline 13 & $\mathrm{CH}_{3}$ & $\mathrm{H}$ & $\mathrm{H}$ & $\mathrm{H}$ \\
\hline 14 & $\mathrm{OCH}_{3}$ & $\mathrm{H}$ & $\mathrm{H}$ & $\mathrm{H}$ \\
\hline 15 & $\mathrm{OC}_{2} \mathrm{H}_{5}$ & $\mathrm{H}$ & $\mathrm{H}$ & $\mathrm{H}$ \\
\hline 16 & $\mathrm{Br}$ & $\mathrm{H}$ & $\mathrm{H}$ & $\mathrm{H}$ \\
\hline 17 & $\mathrm{H}$ & $\mathrm{CH}_{3}$ & $\mathrm{NO}_{2}$ & $\mathrm{H}$ \\
\hline 18 & $\mathrm{H}$ & $\mathrm{H}$ & $\mathrm{H}$ & \\
\hline 19 & $\mathrm{CH}_{3}$ & $\mathrm{H}$ & $\mathrm{H}$ & \\
\hline 20 & $\mathrm{OCH}_{3}$ & $\mathrm{H}$ & $\mathrm{H}$ & \\
\hline 21 & $\mathrm{OC}_{2} \mathrm{H}_{5}$ & $\mathrm{H}$ & $\mathrm{H}$ & \\
\hline 22 & $\mathrm{Cl}$ & $\mathrm{H}$ & $\mathrm{H}$ & \\
\hline
\end{tabular}

Scheme 1. Syntheses of hydrazones 12-22. Azomethine group is marked in green colour and 2-oxindole moiety is represented in purple colour.

In the ${ }^{1} \mathrm{H}$ NMR spectra of hydrazones $\mathbf{1 2}-\mathbf{1 7}$, the proton of the secondary amine group adjacent to the phenyl ring $\left(\mathrm{CH}_{2} \mathrm{NH}\right)$ resonated as a singlet in the region of 5.26-5.97 ppm (Figures S1, S4, S7, S10, S13 and S16 in Supplementary Material). As expected, the amidegroup proton gave a singlet at lower field at $11.12 \mathrm{ppm}$ in the ${ }^{1} \mathrm{H}$ NMR spectra of $\mathbf{1 2}$ and $\mathbf{1 6}$ (Figures S1 and S13 in Supplementary Material). Proton resonance at $10.78 \mathrm{ppm}$ has been attributed to the secondary amine group in the 2-oxindole moiety, thereby-along with the increased intensity of the proton resonances in the aromatic region-confirming the presence of this moiety in the novel compounds. The ${ }^{1} \mathrm{H}$ NMR spectra of hydrazones 13-15 and 17 display double sets of resonances of the $\mathrm{CO}-\mathrm{NH}$ group protons, and a 2-oxindole $\mathrm{NH}$ proton with signal intensity ratio 0.7:0.3 due to the restricted rotation around the amide bond (Figures S4, S7, S10 and S16 in Supplementary Material). This splitting of the proton resonances indicates that in DMSO- $d_{6}$, hydrazones exist as a mixture of $Z / E$ isomers with respect to the hindered rotation around the amide bond. Usually, the $Z$ isomer predominates $[34,35,42]$. In the ${ }^{1} \mathrm{H}$ NMR spectra, the $\mathrm{NH}$ protons of $Z$ isomers resonate at a lower field with respect to the resonances attributed to $E$ isomers [43]. In the ${ }^{13} \mathrm{C} N M R$ spectra for 12-17, two carbonyl group carbon resonances in the range of 162-175 ppm confirm the presence of a 2-oxindole moiety along with the amide group (Figures S2, S5, S8, S11, S14 and S17 in Supplementary Material).

When dihydrazides 7-11 were treated with isatin in the molar ratio 1:2.4, hydrazones 18-22 bearing two 2-oxindole moieties were obtained. In this case, yields of the target compounds were $36-68 \%$. The ${ }^{1} \mathrm{H}$ NMR spectra for 18,19 and 22 display the double sets of amide-group-proton and 2-oxindole-amine-proton resonances, indicating mixtures of $Z / E$ isomers in DMSO- $d_{6}$ solutions (Figure S19, S22 and S31 in Supplementary Material).

With the aim of introducing a 2-oxindole fragment into a structure of a molecule containing the pyrrolidin-2-one moiety, reactions of 5-oxo-1-substituted phenylpyrrolidine- 
3-carbohydrazides $\mathbf{2 3 - 2 5}$ with isatin in the molar ratio 1:1.2 were carried out resulting in the formation of 5-oxo- $\mathrm{N}^{\prime}$-(2-oxoindolin-3-ylidene)pyrrolidine-3-carbohydrazides 26-28 bearing $m$-methoxy, $p$-methoxy, or $p$-chlorophenyl substituents (Scheme 2).<smiles>[R]c1ccc(N2CC(C(N)=O)CC2=O)cc1[R]</smiles>

$23-25$<smiles>NNC(=O)Cn1c(C2CC(=O)N(c3ccc(Cl)cc3)C2)nc2ccccc21</smiles>
29<smiles>[R]c1ccc(N2CC(C(=O)NN=C3C(=O)Nc4ccccc43)CC2=O)cc1[R]</smiles>

26 - 28<smiles>O=C(Cn1c(C2CC(=O)N(c3ccc(Cl)cc3)C2)nc2ccccc21)N/N=C1/C(=O)Nc2ccccc21</smiles>

23, 26: $\mathrm{R}=\mathrm{CH}_{3} ; \mathrm{R}^{\prime}=\mathrm{H} ; 24,27: \mathrm{R}=\mathrm{OCH}_{3} ; \mathrm{R}^{\prime}=\mathrm{H} ; 25,28: \mathrm{R}=\mathrm{H} ; \mathrm{R}^{\prime}=\mathrm{OCH}_{3}$

Scheme 2. Syntheses of hydrazones $\mathbf{2 6 - 2 8}$ and $\mathbf{3 0}$. Azomethine group is marked in green colour and 2-oxindole moiety is represented in purple colour.

2-(2-(1-(4-Chlorophenyl)-5-oxopyrrolidin-3-yl)-1H-benzo[d]imidazol-1-yl)- $N^{\prime}$-(2-oxo indolin-3-ylidene)acetohydrazide (30) was obtained from a corresponding hydrazide 29 in the reaction with isatin (molar ratio 1:1.2). In the ${ }^{1} \mathrm{H}$ NMR spectrum for 30 , two distinct proton sets at $10.78-10.88 \mathrm{ppm}$ and $11.14-11.24 \mathrm{ppm}$ attributed to the amine group proton in 2-oxindole fragment and amide proton are visible, indicating the formation of $Z / E$ isomers in DMSO- $d_{6}$ solutions (Figure S43 in Supplementary Material).

Another set of isatin derivatives were developed by introducing a 2-oxindole fragment into structures of molecules bearing diphenylmethane and diphenylamine along with aliphatic and heterocyclic linkers between the benzene ring and hydrazone-oxindole moiety. First of all, a reaction of 3,3'-((methylenebis(4,1-phenylene))bis(azanediyl))di(propane hydrazide) (31) with isatin in the molar ratio 1:2.4 provided the target compound 32 bearing two $N^{\prime}$-(2-oxoindolin-3-ylidene)propanehydrazide "arms" (Scheme 3).

The next step required the introduction of the pyrrolidin-2-one moiety into the structure of the target compound 35. Thus, 1-[4-(\{4-[4-(methoxycarbonyl)-2-oxopyrrolidine1-il]phenyl\}methyl)phenyl]-5-oxopyrrolidine-3-carboxylate (33) was synthesized by the classical esterification reaction of a corresponding diacid in methanol in the presence of $\mathrm{H}_{2} \mathrm{SO}_{4}$ as a catalyst. Afterwards, diester 33 was dissolved in DMSO and treated with hydrazine hydrate to afford dihydrazide 34 , which was subjected to a reaction with isatin in the molar ratio 1:2.4. Double intensities of the corresponding proton signals in pyrrolidinone and 2-oxindole moieties in the ${ }^{1} \mathrm{H}$ NMR spectra for $33-35$ prove the structures of the target molecules as having two 5-oxo- $N^{\prime}$-(2-oxoindolin-3-ylidene)pyrrolidine-3carbohydrazide "arms" attached to the diphenylmethane core (Figures S49, S52 and S54 in Supplementary Material). 
<smiles>[R]=Cc1ccc(Cc2ccc(C)cc2)cc1</smiles><smiles>NNC(=O)CCNCNCCC(=O)NN</smiles>

31

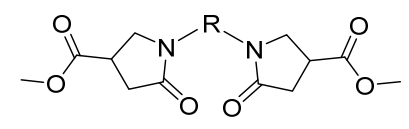

33

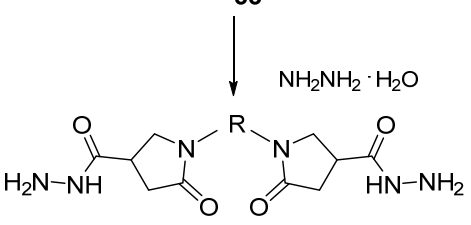

34

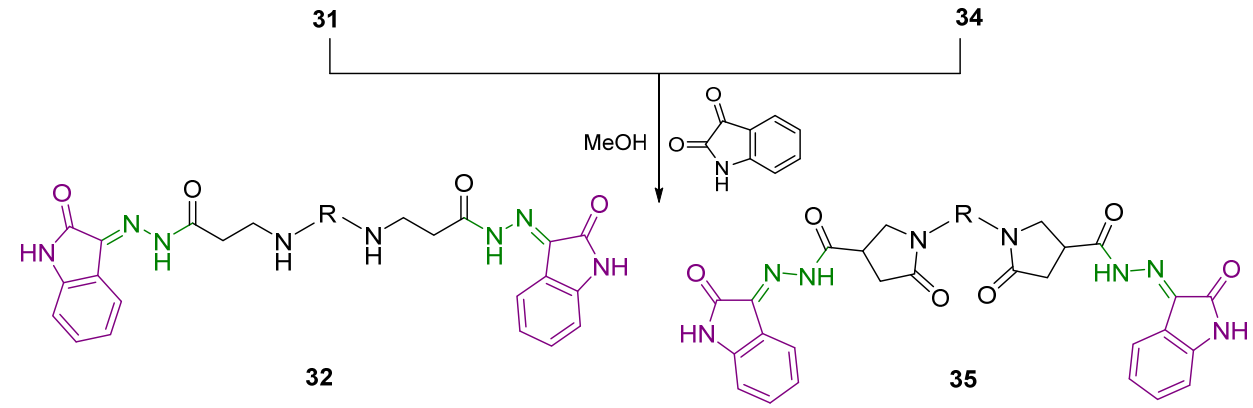

Scheme 3. Synthesis of hydrazones 32 and 35. Azomethine group is marked in green colour and 2-oxindole moiety is represented in purple colour.

Reaction of 4-aminodiphenylamine with itaconic acid at the reflux temperature of the reaction mixture provided 5-oxo-1-(4-(phenylamino)phenyl)pyrrolidine-3-carboxylic acid (36), which was first converted to ester 37 and then to hydrazide 38 according to the classical synthesis procedures (Scheme 4). Hydrazide 38 was treated with isatin in methanol at $65{ }^{\circ} \mathrm{C}$ to afford 5-oxo- $\mathrm{N}^{\prime}$-(2-oxoindolin-3-ylidene)-1-(4-(phenylamino)phenyl)pyrrolidine-3carbohydrazide (39).

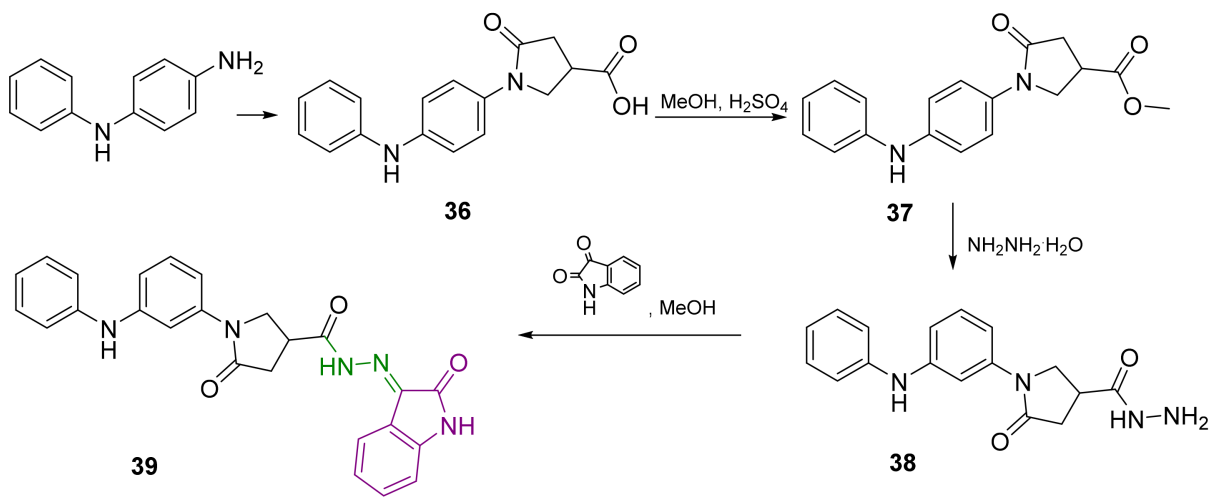

Scheme 4. Synthesis of hydrazone 39. Azomethine group is marked in green colour and 2-oxindole moiety is represented in purple colour.

\subsection{Pharmacology}

\subsubsection{Anticancer Activity}

The synthesized compounds 12-22, 26-28, 30, 32, 35 and 39 showed different levels of activity against human malignant melanoma (A375) and colon adenocarcinoma (HT-29) cell lines at $100 \mu \mathrm{M}$. This concentration was chosen based on our previous experience and the observations from other studies. It has been shown that $100 \mu \mathrm{M}$ allows distinguishing the most active compounds from a group better than $10 \mu \mathrm{M}$ [44]. A $100 \mu \mathrm{M}$ concentration is suggested for primary screenings of anticancer agents [45]. It is also included in experiments as the highest concentration when establishing $\mathrm{EC}_{50}$ values [46,47]. In general, our compounds showed relatively low activity against the A375 cell line used in the screening experiments (Figure 1). Malignant melanoma is usually characterized as a cancer that is poorly responsive to many available chemotherapeutic agents due to 
different drug-resistance mechanisms [48]. HT-29 cells were more sensitive to the majority of the compounds tested. However, they did not have highly cytotoxic effects against this cell line. HT-29 cells are typically resistant to the majority of available drugs due to stemness [37], high expression of the MRP-1 P-glycoprotein that enhances drug efflux [49], and other mechanisms.

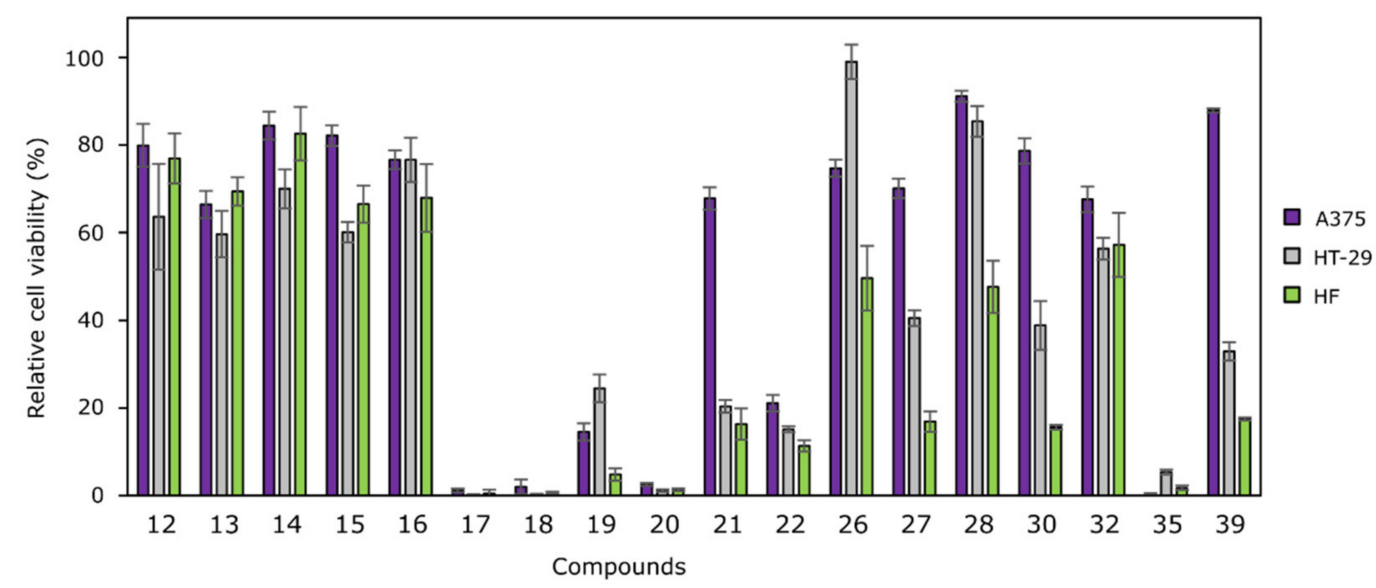

Figure 1. Effects of compounds 12-22, 26-28, 30, 32, 35 and 39 on cancer cell viability at $100 \mu \mathrm{M}$ against human melanoma (A375) and human colon cancer (HT-29) cell lines, and human fibroblasts HF. Cell lines were incubated with $100 \mu \mathrm{M}$ of compounds for $72 \mathrm{~h}$. The cytotoxicity was measured using MTT assays. The cytotoxicity is represented as a percentage of viability, relative to the untreated cells (negative control, which is equal to $100 \%$ ). $\mathrm{N}=3$.

Among mono- $N$-substituted $N^{\prime}$-(2-oxoindolin-3-ylidene)propanehydrazides 12-17, compound 17 bearing the 2-methyl-5-nitrobenzene moiety was identified as the most active one, whereas bis(hydrazone-isatins) $\mathbf{1 8}$ (bearing an unsubstituted benzene ring) and $\mathbf{2 0}$ (bearing the electron-donating methoxy group in benzene ring) were the most active among the compounds with two $N^{\prime}$-(2-oxoindolin-3-ylidene)propanehydrazide "arms." Another compound, which was selected for more thorough testing was diphenylmethane derivative 35 bearing two 5-oxo- $\mathrm{N}^{\prime}$-(2-oxoindolin-3-ylidene)pyrrolidine-3-carbohydrazide "arms" at $p$-positions of benzene rings. These four compounds reduced cell viability below $10 \%$. The effective concentrations that reduced cell viability by $50 \%$ ( $\mathrm{EC}_{50}$ values) were determined (Figure 2).

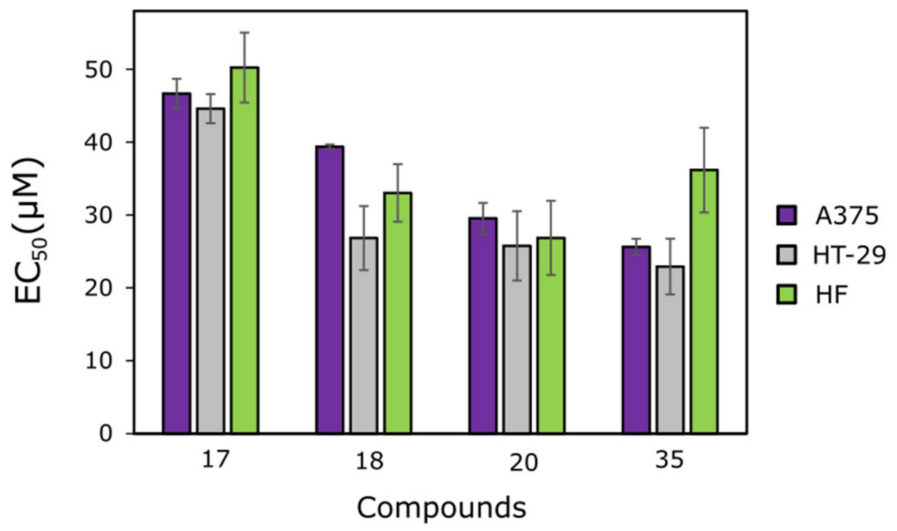

Figure 2. $\mathrm{EC}_{50}$ values of the most active compounds: 17, 18, 20 and 35. Cell lines were incubated with different concentrations of those compounds for $72 \mathrm{~h}$. The cytotoxicity was measured using MTT assays. The cytotoxicity is represented as the calculated half maximal effective concentration (EC 50 value). $\mathrm{N}=3$. 
The mono-hydrazone-isatin 17, bearing an electron-withdrawing nitro group at the $o$-position of the benzene ring, was the least active out of the four compounds selected, and it did not possess any selectivity towards cancer cell lines $\left(\mathrm{EC}_{50}=46.7 \pm 2.0 \mu \mathrm{M}\right.$ against $\mathrm{A} 375$, and $\mathrm{EC}_{50}=44.6 \pm 2.0 \mu \mathrm{M}$ against HT-29) compared to fibroblasts $\left(\mathrm{EC}_{50}=50.2 \pm\right.$ $4.8 \mu \mathrm{M})$. The cytotoxic effects of bis(hydrazone-isatins) 20 and $\mathbf{3 5}$ were similar against both cell lines; however, compound 35 showed less cytotoxicity toward fibroblasts, and this makes it a more promising one.

As a comparison, dacarbazine, which is a chemotherapeutic drug approved for melanoma treatment, is far less active and inhibits A375 cell survival only at high concentrations of 25-100 $\mu \mathrm{M}$ [50]. However, the clinically approved BRAF inhibitor dabrafenib reduces A375 cell viability by $50 \%$ at a nanomolar concentration after $72 \mathrm{~h}$ of incubation [51]. 5-Fluorouracil, which is approved as a chemotherapeutic agent against colon cancer, possesses a rather low cytotoxic effect after $72 \mathrm{~h}$ of incubation, and usually five or more days are needed for it to reach its $\mathrm{EC}_{50}$ value, which is $>100 \mu \mathrm{M}$ [52]. The kinase inhibitor regorafenib achieves 50\% HT-29 cell viability reduction at $0.5 \mu \mathrm{M}$ concentration after $6 \mathrm{~h}$ of incubation [53].

A clonogenic assay was used to evaluate each compound's impact on the ability of a single cell to form a colony. Numbers of colonies (ability of single cells to survive) and the areas of colonies (ability to form a colony and proliferate) were determined. The most active compounds, 17, 18, 20 and 35, were tested for their activity against human melanoma (A375) and colon adenocarcinoma (HT-29) cell lines at $50 \%$ of their $\mathrm{EC}_{50}$ values.

The synthesized compounds showed higher activity against HT-29 colony formation (Figure 3). Derivatives $\mathbf{1 7}$ and $\mathbf{1 8}$ did not affect A375 colony number or colony area, compared to the control ( $\mathrm{p}>0.05$ ), although both compounds slowed down the colony proliferation. Compound $\mathbf{2 0}$ was identified as the most active compound; its inhibitory effect on the ability to proliferate and form colonies was the highest. For instance, in A375 and HT-29 cell lines, the colony areas dropped down to $78.9 \%$ and $60.6 \%$, respectively, and reached their lowest values in comparison to the control cells (Figure 3). The activity of diphenylmethane derivative 35 was similar to that of bis(hydrazone-isatin) 20 bearing the electron-donating methoxy group at $p$-position of benzene ring.

Malignant melanoma is one of the most aggressive tumor types, and A375 is characterized by high proliferation and migration rates, and high invasiveness potential [38]. This suggests the need to identify novel molecular targets and new therapeutic strategies. The combination strategy is one of the possible solutions that can overcome the resistance of melanoma cells to conventional therapy. Li and Han [54] have shown that a combination of dacarbazine and all-trans retinoic acid, loaded in lipid nanoformulations, is able to reduce B16F10's colony formation ability, whereas dacarbazine alone shows a limited ability to inhibit colony formation. In several studies, the colony-forming effect of kinase inhibitors was assessed by clonogenic assay. Sinik et al. [55] determined that MERTK inhibitor UNC2025 decreased colony formation and cell density in most tested BRAF mutant and BRAF wild-type cell lines at 300-500 nM. Ross et al. [39] have determined that the antifolate methotrexate sensitizes resistant malignant melanoma cells to the kinase inhibitor dabrafenib, and their combination reduces colony formation by up to $42.5 \%$ relative to dabrafenib alone. Similarly, colon cancer is considered to be one of the most aggressive cancers worldwide, and it gains resistance to drugs quite often [37]. In order to combat the resistance, the approach of pretreating cancer cells with other compounds before adding chemotherapeutic agents is widely studied. By using clonogenic assays, it has been shown that the kinase inhibitor dasatinib could have a favorable synergistic effect with oxaliplatin, which is an approved drug for colon adenocarcinoma treatment [40]. A combination of $100 \mathrm{nM}$ dasatinib and $2.5 \mu \mathrm{M}$ oxaliplatin significantly reduced HT-29 (but not KM12-L4) colony growth after 14 days of incubation. In summary, the effects of different compounds on colony-forming ability depends a lot on the cell line used, and kinase inhibitors could sensitize cells to cytotoxic drugs. In our case, the hydrazone-isatin derivatives bear kinase 
inhibitor fragments and are supposed to have a similar mechanism of action. However, deeper analysis of mechanisms of action is needed.
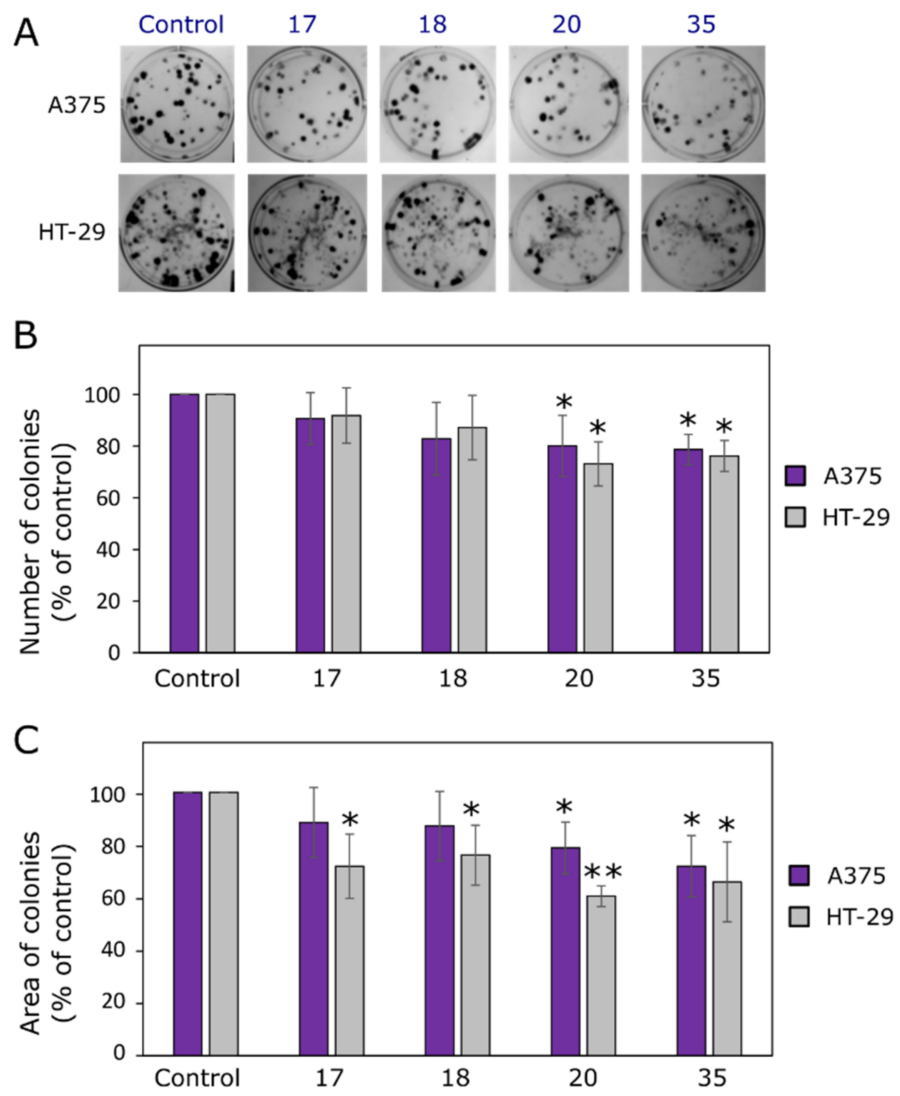

Figure 3. Effects of compounds 17, 18, 20 and 35 on colony formation. (A) Photos of A375 and HT-29 colonies at the end of the experiment. (B) Numbers of colonies at the end of the experiment. (C) Areas of colonies at the end of the experiment. Single asterisks $\left({ }^{*}\right)$ indicate $p<0.05$ and pairs $\left(^{* *}\right)$ indicate $p<0.01$ compared to the control (untreated cell colonies).

Nowadays, 3D cell culture models are becoming popular among cancer biologists due to the spatial arrangement of cells, and they enable the formation of hypoxia inside and a gradient of tested substances $[41,56]$. Such a model resembles a real tumor microenvironment and is more reminiscent of a real tumor than conventional cell monolayers. Thus, the effects of 20 and $50 \mu \mathrm{M}$ solutions of bis(hydrazone-isatins) 18, 20, and 35 on melanoma A375 and colon adenocarcinoma HT-29 cell spheroid growth (Figure 4) were studied. As shown in Figure 4C, all tested compounds reduced A375 spheroid growth by $120 \%$ at the higher concentration of $50 \mu \mathrm{M}$ in comparison to the control group. Diphenylmethane derivative 35 showed an inhibitory effect on A375 spheroid growth at a concentration of $20 \mu \mathrm{M}$, too. Meanwhile, the effect on HT-29 3D culture growth was lower. Only compound 35 statistically significantly inhibited colon cancer cell spheroid growth (by $\sim 105 \%$ ) in comparison with the control (Figure 4C). 
A

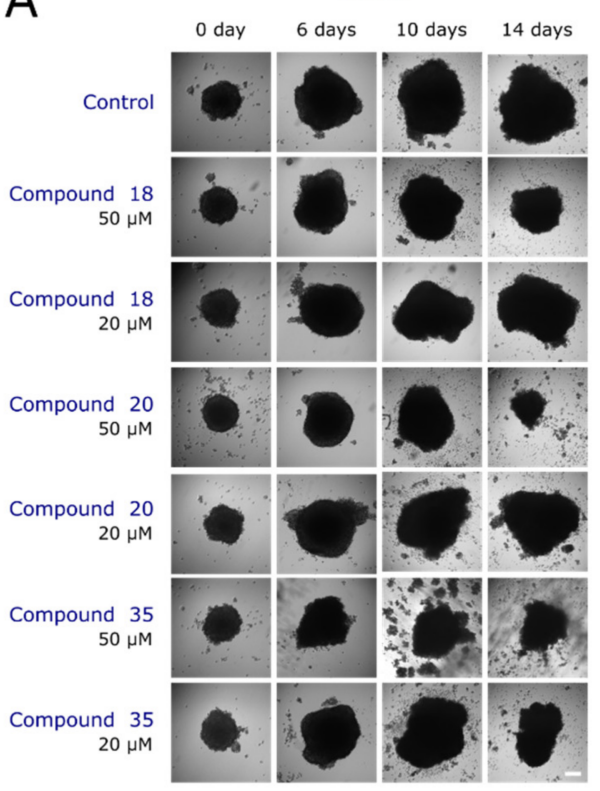

C

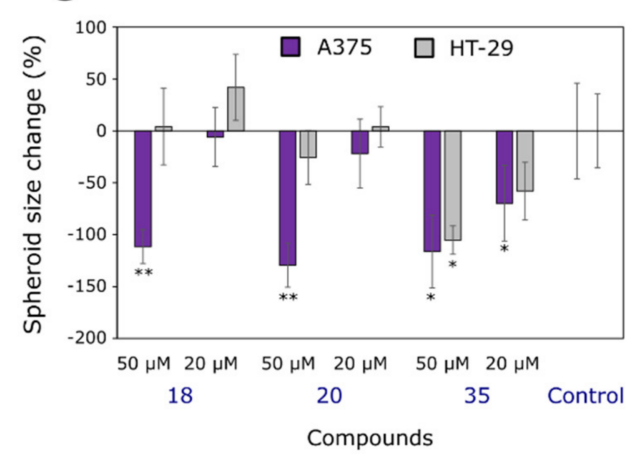

B

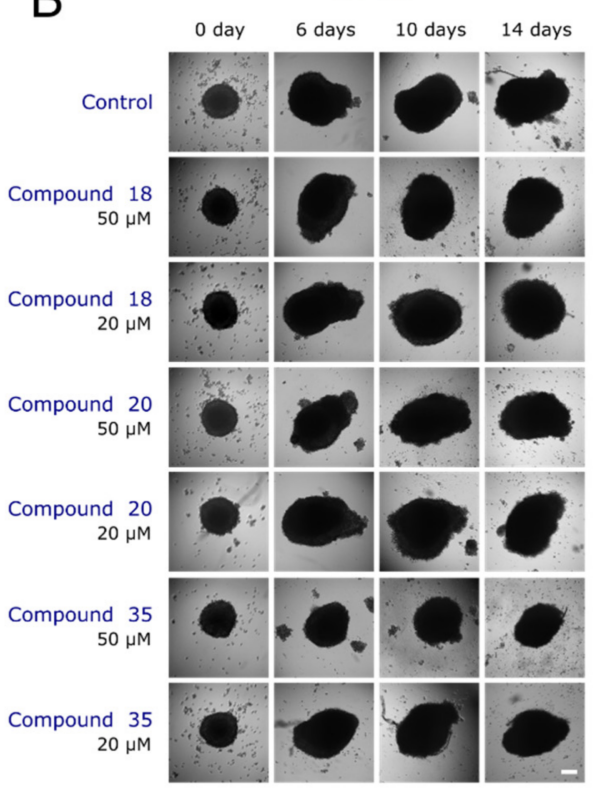

D

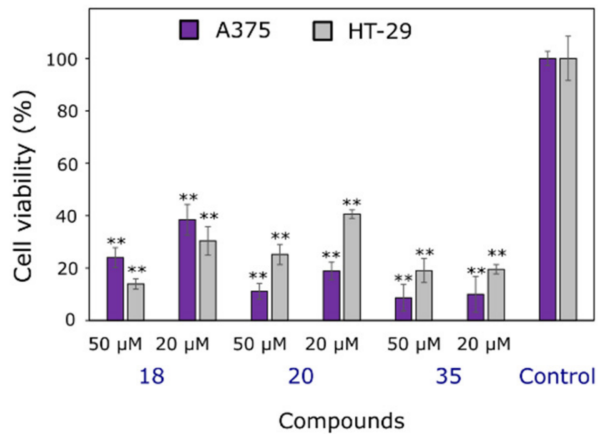

Figure 4. Effects of compounds 18, 20 and 35 on 3D cell cultures. (A) Photos of human melanoma (A375) tumor spheroids at different periods of the experiment. (B) Photos of human colon adenocarcinoma (HT-29) tumor spheroids at different periods of the experiment. (C) Spheroid size at the end of the experiment. (D) Cell viability in A375 and HT-29 spheroids. Single asterisks (*) indicate $p<0.05$, and pairs $(* *)$ indicate $p<0.01$ compared to the control (untreated spheroids). Scale bars indicate $100 \mu \mathrm{m}$.

While taking into account that spheroid size does not always necessarily correlate with viability [57], we decided to study cell viability in all groups at the end of the experiment (Figure 4D). Interestingly, cell viability was from 2.5-fold to 10-fold lower compared to the control for both types of spheroids. This could be explained by cells at the cores of the spheroids being more affected by the compound, thereby becoming more hypoxic or even necrotic, denser, and less viable. Some spheroids at the end of the experiment became looser and irregular in shape, and started to disintegrate (Figure 4A,B). However, Golas et al. [58] determined that SKI-606, an inhibitor of Src and Abl kinases at the concentration of $2.5 \mu \mathrm{M}$, reduced the HT-29 spheroid size after the 6 days of incubation and concluded that SKI-606 strengthens cell-cell interactions. Cell viability was not measured at the end of this experiment, but the hypothesis regarding cell-cell interaction protection against SKI-606 treatment has been formed. Another study by Folkesson et al. [59] has revealed that MEK and TAK1 inhibitors strongly reduce cell viability both in 2D and 3D cell cultures, and combined treatments with a MEK inhibitor and conventional drugs produce synergistic effects in 3D models. Meanwhile, MEK inhibitors combined with STAT3 small-molecule 
inhibitors can cause cell death in 3D cultures [60]. This means that kinase inhibitors could be beneficial in reducing cell viability and inhibiting the growth of cells in 2D models.

In summary, compounds $\mathbf{2 0}$ and $\mathbf{3 5}$ have been identified as the most promising anticancer agents out of the series of hydrazone-isatin derivatives. Though their cytotoxicity against both cancer cell lines was not very high $\left(\mathrm{EC}_{50}\right.$ values were in the range of $\left.22-30 \mu \mathrm{M}\right)$, they were more active than dacarbazine 5-fluorouracil and reforafenib, which are used to treat malignant melanoma and colon cancer. It is worth mentioning that the selectivity of the most promising compounds towards cancer cells (in comparison to fibroblasts) was not high. Compound 35 alone was 1.6 times more active against A375 and 1.4 times more selective against HT-29 compared to fibroblasts. However, the selectivity studies were performed in cell monolayers, and this is only the first step toward identifying the most active scaffolds for further development of more selective and more active anticancer agents. It should be worth exploring the accumulation of modified compounds in more sophisticated models, e.g., the three-dimensional models combining both fibroblasts and cancer cells, and thereby evaluating the fractions and types of surviving cells after compound treatment. Furthermore, the selectivity towards tumors is a major problem for many (even clinically-available) cytotoxic agents. Currently, many different approaches are used to improve selectivity, such as packing molecules into nanoformulations [61] and conjugating cytotoxic agents to antibodies [62].

\subsubsection{Antioxidant Activity}

Reactive oxygen species (ROS) and reactive nitrogen species (NOS) are well known as both harmful and beneficial species [63]. However, imbalances between endogenous antioxidant defense and ROS oxidative stress have been related to an extensive range of diseases, including cardiovascular, inflammatory, neurodegenerative, and autoimmune ones. Overproduction of ROS can be responsible for damage to vital cell components, especially to DNA, lipids, and proteins. It is known that the use of antioxidants is beneficial in the prevention or delaying of numerous diseases associated with oxidative stress, including cancer, Alzheimer's and other neurodegenerative diseases, and atherosclerosis [64-67]. Antioxidants are believed to prevent and treat various types of malignancies [68]. The compounds $12-22,26-28,30,32,35$ and 39 were designed to contribute to radical-scavenging (to be antioxidants) [69,70].

Ferric ion $\left(\mathrm{Fe}^{3+}\right)$, which is a relatively biologically inactive form of iron, can be reduced to the active $\mathrm{Fe}^{2+}$ depending on the conditions, particularly $\mathrm{pH}$, and oxidized back through a Fenton-type reaction with the production of hydroxyl radicals or a Haber-Weiss reaction with the generation of superoxide anions [71,72]. Reducing power measures the reductive ability of an antioxidant, and it is evaluated by the transformation of $\mathrm{Fe}^{3+}$ to $\mathrm{Fe}^{2+}$ by donation of an electron in the presence of the tested compound [73].

As seen from the results presented in Figure 5, compounds 32, 35 and 39 possessed the highest capacity to reduce $\mathrm{Fe}(\mathrm{TPTZ})^{3+}$ to $\mathrm{Fe}(\mathrm{TPTZ})^{2+}$ in comparison with the positive control, ascorbic acid $(103.41 \mu \mathrm{M})$. It is interesting to note that compounds 32 and 35 are bis(hydrazone-isatins), and compound 39 has just one 5-oxo- $N^{\prime}$-(2-oxoindolin-3ylidene)pyrrolidine-3-carbohydrazide "arm." The relatively high ferric reducing antioxidant power of 39 proves the expectation that substitution of diphenylmethane with a diphenylamine moiety bearing a secondary amine group [74] enhances the reducing power of compound 39. Another group of compounds which have been identified as possessing high antioxidant activity comprises bis(hydrazone-isatins) 19-21, whose structures differ by a substituent at the $p$-position of benzene ring. Compound 20 bearing the electron-donating methoxy group in the benzene ring has shown higher radical scavenging ability than $\mathbf{1 9}$ and 21. Compounds 19-21 have been found to be considerably more active than their analogues bearing just one $N^{\prime}$-(2-oxoindolin-3-ylidene)propanehydrazide "arm": 13-15. In this group, the ethoxy substituent in $\mathbf{1 5}$ had a more significant positive effect on the activity of the molecule. In another group of compounds, 26-28, bearing a pyrrolidin-2-one ring as a linker between the hydrazine-oxindole moiety and the $p$-substituted benzene ring, 
compound 26, containing an electron-donating methyl group, was identified as the least active one. The position of the methoxy substituent in the benzene ring had no significant influence on the antioxidant activity of 27 and 28.

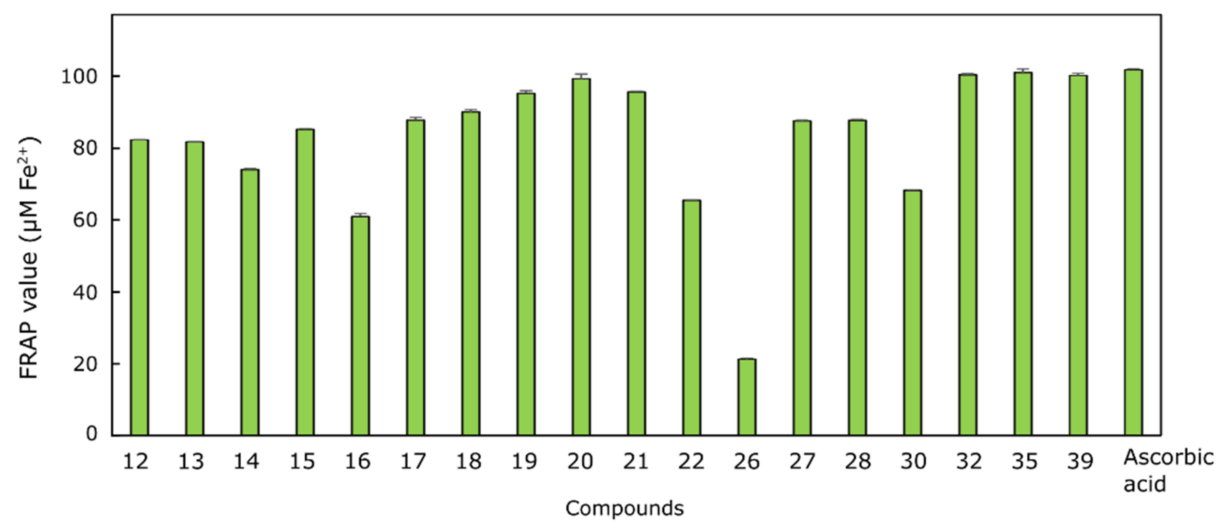

Figure 5. Antioxidant activity levels of compounds 12-22, 26-28, 30, 32, 35 and 39 tested by Ferric reducing antioxidant power assay. For each assay, $100 \mu \mathrm{L}$ each of the tested compound solution $(20 \mathrm{mM})$ and positive control $(20 \mathrm{mM}$ ascorbic acid) were mixed with $3 \mathrm{~mL}$ of the FRAP reagent (negative control: $3 \mathrm{~mL}$ FRAP reagent and $100 \mu \mathrm{L}$ DMSO). The absorbance of the reaction mixture at $593 \mathrm{~nm}$ was measured spectrophotometrically after $5 \mathrm{~min}$.

\section{Materials and Methods}

\subsection{Chemistry}

\subsubsection{Chemical Reagents and Instruments}

Reagents were purchased from Sigma-Aldrich (St. Lous, MO, USA) and TCI Europe N.V. (Zwijndrecht, Belgium). Reaction course and purity of the synthesized compounds were monitored by TLC using aluminum plates precoated with silica gel 60 F254 (MerckKGaA, Darmstadt, Germany). Melting points were determined on a MEL-TEMP (Electrothermal, A Bibby Scientific Company, Burlington, NJ, USA) melting point apparatus and are uncorrected. FT-IR spectra $\left(\nu, \mathrm{cm}^{-1}\right)$ were recorded on a Perkin-Elmer Spectrum BX FT-IR spectrometer using $\mathrm{KBr}$ pellets. The ${ }^{1} \mathrm{H}$ and ${ }^{13} \mathrm{C}-\mathrm{NMR}$ spectra were recorded in DMSO- $d_{6}$ on a Bruker Avance III $(400 \mathrm{MHz}, 101 \mathrm{MHz})$ spectrometer operating in Fourier transform mode. Chemical shifts $(\delta)$ are reported in parts per million (ppm) calibrated from TMS (0 ppm) as an internal standard for ${ }^{1} \mathrm{H}$ NMR, and DMSO- $d_{6}(39.43 \mathrm{ppm})$ for ${ }^{13} \mathrm{C}$ NMR. Mass spectra were obtained on the Bruker maXis UHR-TOF mass spectrometer (Bruker Daltonics, Bremen, Germany) with ESI ionization.

\subsubsection{General Procedure for Synthesis of Compounds 12-17}

To a solution of a corresponding hydrazide $(5 \mathrm{mmol})$ in methanol $(25 \mathrm{~mL})$, isatin $(6 \mathrm{mmol})$ and glacial acetic acid (5 drops) were added. The reaction mixture was stirred at $65{ }^{\circ} \mathrm{C}$ for $15-20 \mathrm{~min}$. Precipitate was filtered off, washed with methanol, and recrystallized from $\mathrm{DMF} / \mathrm{H}_{2} \mathrm{O}$ mixture.

$N^{\prime}$-(2-oxoindolin-3-ylidene)-3-(phenylamino)propanehydrazide (12)

Prepared from 3-(phenylamino)propanehydrazide (1) [75] (0.89 g). Yield 68\% (1.05 g); yellow crystals; m.p. 207-208 ${ }^{\circ} \mathrm{C}$; IR (KBr) $v_{\max }\left(\mathrm{cm}^{-1}\right): 1695,1728(\mathrm{C}=\mathrm{O}), 3258,3355$, $3447(\mathrm{NH}) ;{ }^{1} \mathrm{H}$ NMR $\left(400 \mathrm{MHz}, \mathrm{DMSO}-d_{6}\right): \delta 2.63-3.11\left(\mathrm{~m}, 2 \mathrm{H}, \mathrm{CH}_{2} \mathrm{CO}\right), 3.33-3.42(\mathrm{~m}, 2 \mathrm{H}$, $\left.\mathrm{CH}_{2} \mathrm{NH}\right), 5.69\left(\mathrm{~s}, 1 \mathrm{H}, \mathrm{CH}_{2} \mathrm{NH}\right), 6.55\left(\mathrm{t}, 1 \mathrm{H}, J=8.0 \mathrm{~Hz}, \mathrm{H}_{\mathrm{Ar}}\right), 6.63\left(\mathrm{~d}, 2 \mathrm{H}, J=8.0 \mathrm{~Hz}, \mathrm{H}_{\mathrm{Ar}}\right)$, $6.89\left(\mathrm{~d}, 1 \mathrm{H}, J=8.0 \mathrm{~Hz}, \mathrm{H}_{\mathrm{Ar}}\right), 6.92-6.99\left(\mathrm{~m}, 1 \mathrm{H}, \mathrm{H}_{\mathrm{Ar}}\right), 7.09\left(\mathrm{t}, 2 \mathrm{H}, J=8.0 \mathrm{~Hz}, \mathrm{H}_{\mathrm{Ar}}\right), 7.36(\mathrm{t}$, $\left.1 \mathrm{H}, J=8.0 \mathrm{~Hz}, \mathrm{H}_{\mathrm{Ar}}\right), 7.76-8.30\left(\mathrm{~m}, 1 \mathrm{H}, \mathrm{H}_{\mathrm{Ar}}\right), 10.78$ (s, 1H, $\left.\mathrm{NH}_{\text {isatin }}\right), 11.12(\mathrm{~s}, 1 \mathrm{H}, \mathrm{NHCO})$; ${ }^{13} \mathrm{C}$ NMR (101 MHz, DMSO- $\left.d_{6}\right): \delta 34.23\left(\mathrm{CH}_{2} \mathrm{CO}\right), 38.38\left(\mathrm{CH}_{2} \mathrm{NH}\right), 110.56,112.24,115.30$, 115.90, 121.63, 126.02, 128.98, 132.43, 143.65, $148.49\left(\mathrm{C}_{\mathrm{Ar}}\right), 164.67,170.35(\mathrm{C}=\mathrm{O})$; HRMS (ESI): $m / z$ calcd for $\mathrm{C}_{17} \mathrm{H}_{16} \mathrm{~N}_{4} \mathrm{O}_{2} 309.1352[\mathrm{M}+\mathrm{H}]^{+}$, found 309.1346 .

$N^{\prime}$-(2-oxoindolin-3-ylidene)-3-( $p$-tolylamino)propanehydrazide (13) 
Prepared from 3-(p-tolylamino)propanehydrazide (2) [76,77] (0.97 g). Yield 96\% (1.54 g); yellow crystals; m.p. 215-216 ${ }^{\circ} \mathrm{C}$; IR (KBr) $v_{\max }\left(\mathrm{cm}^{-1}\right): 1694,1728(\mathrm{C}=\mathrm{O}), 3132$, 3244, $3356(\mathrm{NH}) ;{ }^{1} \mathrm{H}$ NMR $\left(400 \mathrm{MHz}, \mathrm{DMSO}-d_{6}\right): \delta 2.14\left(\mathrm{~s}, 3 \mathrm{H}, \mathrm{CH}_{3}\right), 2.63-3.39(\mathrm{~m}, 4 \mathrm{H}$, $\left.\mathrm{CH}_{2} \mathrm{CO}+\mathrm{CH}_{2} \mathrm{NH}\right), 5.46\left(\mathrm{~s}, 1 \mathrm{H}, \mathrm{CH}_{2} \mathrm{NH}\right), 6.47-6.57\left(\mathrm{~m}, 2 \mathrm{H}, \mathrm{H}_{\mathrm{Ar}}\right), 6.86-6.95\left(\mathrm{~m}, 3 \mathrm{H}, \mathrm{H}_{\mathrm{Ar}}\right)$, $7.08\left(\mathrm{t}, 1 \mathrm{H}, J=8.0 \mathrm{~Hz}, \mathrm{H}_{\mathrm{Ar}}\right), 7.36\left(\mathrm{t}, 1 \mathrm{H}, J=8.0 \mathrm{~Hz}, \mathrm{H}_{\mathrm{Ar}}\right), 7.40-7.64\left(\mathrm{~m}, 1 \mathrm{H}, \mathrm{H}_{\mathrm{Ar}}\right), 10.77$ (s, 0.3H, NHCO), 11.11 (s, 0.3H, $\left.\mathrm{NH}_{\text {isatin }}\right), 11.23$ (s, 0.7H, $\left.\mathrm{NH}_{\text {isatin }}\right), 12.54,12.97(2 \mathrm{~s}, 0.7 \mathrm{H}$, $\mathrm{NHCO}) ;{ }^{13} \mathrm{C}$ NMR (101 MHz, DMSO-d 6 ): $\delta 20.08\left(\mathrm{CH}_{3}\right), 31.16\left(\mathrm{CH}_{2} \mathrm{CO}\right), 40.19\left(\mathrm{CH}_{2} \mathrm{NH}\right)$, $111.09,112.28,115.28,121.61,122.50,124.21,125.99,129.37,131.39,133.91,142.29,146.18$ $\left(\mathrm{C}_{\text {Ar }}\right), 162.46,173.86(\mathrm{C}=\mathrm{O})$; HRMS (ESI): $m / z$ calcd for $\mathrm{C}_{18} \mathrm{H}_{18} \mathrm{~N}_{4} \mathrm{O}_{2} 323.1509[\mathrm{M}+\mathrm{H}]^{+}$, found 323.1503 .

3-((4-Methoxyphenyl)amino)- $N^{\prime}$-(2-oxoindolin-3-ylidene)propanehydrazide (14)

Prepared as described in [35].

3-((4-Ethoxyphenyl)amino)- $N^{\prime}$-(2-oxoindolin-3-ylidene)propanehydrazide (15)

Prepared from 3-((4-ethoxyphenyl)amino)propanehydrazide (4) [78] (1.12 g). Yield $58 \%$ (0.97 g); yellow crystals; m.p. 208-209 ${ }^{\circ} \mathrm{C}$. IR (KBr) $v_{\max }\left(\mathrm{cm}^{-1}\right): 1695,1728(\mathrm{C}=\mathrm{O})$, 3156, 3267, $3341(\mathrm{NH}) ;{ }^{1} \mathrm{H}$ NMR $\left(400 \mathrm{MHz}, \mathrm{DMSO}-d_{6}\right): \delta 1.26\left(\mathrm{t}, 3 \mathrm{H}, J=6.9 \mathrm{~Hz}, \mathrm{CH}_{3} \mathrm{CH}_{2} \mathrm{O}\right)$, 2.66-3.10 (m, 2H, CH $\left(\mathrm{s}, 1 \mathrm{H}, \mathrm{CH}_{2} \mathrm{NH}\right), 6.54-6.60\left(\mathrm{~m}, 2 \mathrm{H}, \mathrm{H}_{\mathrm{Ar}}\right), 6.72\left(\mathrm{t}, 2 \mathrm{H}, \mathrm{J}=8.0 \mathrm{~Hz}, \mathrm{H}_{\mathrm{Ar}}\right), 6.88-7.09(\mathrm{~m}, 2 \mathrm{H}$, $\left.\mathrm{H}_{\mathrm{Ar}}\right), 7.36\left(\mathrm{t}, 1 \mathrm{H}, J=8.0 \mathrm{~Hz}, \mathrm{H}_{\mathrm{Ar}}\right), 7.47-8.14\left(\mathrm{~m}, 1 \mathrm{H}, \mathrm{H}_{\mathrm{Ar}}\right), 10.78$ (s, 0.7H, NHCO), 11.14 (s, $\left.0.7 \mathrm{H}, \mathrm{NH}_{\text {isatin }}\right), 11.23\left(\mathrm{~s}, 0.3 \mathrm{H}, \mathrm{NH}_{\text {isatin }}\right), 12.54,12.97(2 \mathrm{~s}, 0.3 \mathrm{H}, \mathrm{NHCO}) ;{ }^{3} \mathrm{C} \mathrm{NMR}(101 \mathrm{MHz}$, DMSO-d $\left.d_{6}\right): \delta 14.89\left(\mathrm{CH}_{3} \mathrm{CH}_{2} \mathrm{O}\right), 31.17\left(\mathrm{CH}_{2} \mathrm{CO}\right), 40.19\left(\mathrm{CH}_{2} \mathrm{NH}\right), 63.30\left(\mathrm{CH}_{2} \mathrm{CH}_{2} \mathrm{O}\right), 110.55$, 113.26, 115.28, 115.45, 121.61, 125.97, 131.40, 132.42, 142.65, 143.63, $150.03\left(\mathrm{C}_{\mathrm{Ar}}\right), 162.47$, $173.92(\mathrm{C}=\mathrm{O})$; HRMS (ESI): $m / z$ calcd for $\mathrm{C}_{19} \mathrm{H}_{20} \mathrm{~N}_{4} \mathrm{O}_{3} 353.1614[\mathrm{M}+\mathrm{H}]^{+}$, found 353.1608 .

3-((4-Bromophenyl)amino)- $N^{\prime}$-(2-oxoindolin-3-ylidene)propanehydrazide (16)

Prepared from 3-((4-bromophenyl)amino)propanehydrazide (5) [79] (1.29 g). Yield 73\% (1.41 g); yellow crystals; m.p. $218-219{ }^{\circ} \mathrm{C}$. IR (KBr) $v_{\max }\left(\mathrm{cm}^{-1}\right): 1695,1726(\mathrm{C}=\mathrm{O})$, 3136, 3257, $3356(\mathrm{NH}) ;{ }^{1} \mathrm{H}$ NMR (400 MHz, DMSO-d $\left.)_{6}\right): \delta 2.69-3.17$ (m, 2H, $\left.\mathrm{CH}_{2} \mathrm{CO}\right), 3.35$ $\left(\mathrm{s}, 2 \mathrm{H}, \mathrm{CH}_{2} \mathrm{NH}\right), 5.97\left(\mathrm{~s}, 1 \mathrm{H}, \mathrm{CH}_{2} \mathrm{NH}\right), 6.60\left(\mathrm{~d}, 2 \mathrm{H}, \mathrm{J}=8.0 \mathrm{~Hz}, \mathrm{H}_{\mathrm{Ar}}\right), 6.89(\mathrm{~d}, 1 \mathrm{H}, J=8.0 \mathrm{~Hz}$, $\left.\mathrm{H}_{\mathrm{Ar}}\right), 7.00\left(\mathrm{t}, 1 \mathrm{H}, J=8.0 \mathrm{~Hz}, \mathrm{H}_{\mathrm{Ar}}\right), 7.21\left(\mathrm{~d}, 2 \mathrm{H}, J=8.0 \mathrm{~Hz}, \mathrm{H}_{\mathrm{Ar}}\right), 7.36(\mathrm{t}, 1 \mathrm{H}, J=8.0 \mathrm{~Hz}$, $\left.\mathrm{H}_{\mathrm{Ar}}\right), 7.80-8.21\left(\mathrm{~m}, 1 \mathrm{H}, \mathrm{H}_{\mathrm{Ar}}\right), 10.78$ (s, 1H, NH $\left.\mathrm{Nsatin}\right), 11.12$ (s, 1H, NHCO); ${ }^{13} \mathrm{C} \mathrm{NMR} \mathrm{(101}$ $\left.\mathrm{MHz}, \mathrm{DMSO}-d_{6}\right): \delta 32.27\left(\mathrm{CH}_{2} \mathrm{CO}\right), 38.41\left(\mathrm{CH}_{2} \mathrm{NH}\right), 106.36,110.55,114.10,115.27,121.62$, 126.07, 131.45, 132.41, 143.65, $147.72\left(\mathrm{C}_{\mathrm{Ar}}\right), 164.63,175.44(\mathrm{C}=\mathrm{O})$; HRMS $(\mathrm{ESI}): \mathrm{m} / \mathrm{z}$ calcd for $\mathrm{C}_{17} \mathrm{H}_{15} \mathrm{BrN}_{4} \mathrm{O}_{2} 387.0457[\mathrm{M}+\mathrm{H}]^{+}$, found 387.0451 .

3-((2-Methyl-5-nitrophenyl)amino)-N'-(2-oxoindolin-3-ylidene)propanehydrazide (17)

Prepared from 3-((2-methyl-5-nitrophenyl)amino)propanehydrazide (6) [76,80] (1.2 g). Yield 95\% (1.93 g); yellow crystals; m.p. 205-206 ${ }^{\circ} \mathrm{C}$; IR (KBr) $v_{\max }\left(\mathrm{cm}^{-1}\right): 1699,1729$ $(\mathrm{C}=\mathrm{O}), 3160,3191,3419(\mathrm{NH}) ;{ }^{1} \mathrm{H}$ NMR $\left(400 \mathrm{MHz}, \mathrm{DMSO}-d_{6}\right): \delta 2.16\left(\mathrm{~s}, 3 \mathrm{H}, \mathrm{CH}_{3}\right), 2.73-3.18$ (m, 2H, CH $\left.\mathrm{CH}_{2} \mathrm{CO}\right), 3.47-3.63\left(\mathrm{~m}, 2 \mathrm{H}, \mathrm{CH}_{2} \mathrm{NH}\right), 5.66\left(\mathrm{~s}, 1 \mathrm{H}, \mathrm{CH}_{2} \mathrm{NH}\right), 6.85-6.94\left(\mathrm{~m}, 1 \mathrm{H}, \mathrm{H}_{\mathrm{Ar}}\right)$, $7.00\left(\mathrm{t}, 1 \mathrm{H}, J=8.0 \mathrm{~Hz}, \mathrm{H}_{\mathrm{Ar}}\right), 7.21\left(\mathrm{~d}, 2 \mathrm{H}, J=8.0 \mathrm{~Hz}, \mathrm{H}_{\mathrm{Ar}}\right), 7.28-7.42\left(\mathrm{~m}, 3 \mathrm{H}, \mathrm{H}_{\mathrm{Ar}}\right), 7.80-8.19$ $\left(\mathrm{m}, 1 \mathrm{H}, \mathrm{H}_{\mathrm{Ar}}\right), 10.77$ (s, 0.7H, NHCO), $11.12\left(\mathrm{~s}, 0.7 \mathrm{H}, \mathrm{NH}_{\text {isatin }}\right), 11.23$ (s, 0.3H, $\left.\mathrm{NH}_{\text {isatin }}\right), 12.57$, 12.96 (2s, 0.3H, NHCO); ${ }^{13} \mathrm{C}$ NMR (101 MHz, DMSO-d $): \delta 17.88\left(\mathrm{CH}_{3}\right), 40.19\left(\mathrm{CH}_{2} \mathrm{CO}\right)$, $46.73\left(\mathrm{CH}_{2} \mathrm{NH}\right), 102.25,110.56,111.10,115.28,121.61,126.05,130.21,130.37,132.45,142.30$, 143.66, 147.01, 147.22 ( $\left.\mathrm{C}_{\mathrm{Ar}}\right), 162.47,164.65(\mathrm{C}=\mathrm{O})$; HRMS (ESI): $m / z$ calcd for $\mathrm{C}_{18} \mathrm{H}_{17} \mathrm{~N}_{5} \mathrm{O}_{4}$ $368.1360[\mathrm{M}+\mathrm{H}]^{+}$, found 368.1353 .

\subsubsection{General Procedure for Synthesis of Compounds 18-22}

To a solution of corresponding hydrazide $(5 \mathrm{mmol})$ in methanol $(25 \mathrm{~mL})$, isatin (12 mmol) and glacial acetic acid (5 drops) were added. The reaction mixture was stirred at $65{ }^{\circ} \mathrm{C}$ for $15 \mathrm{~min}$. Precipitate was filtered off, washed with methanol, and recrystallized from $\mathrm{DMF} / \mathrm{H}_{2} \mathrm{O}$ mixture.

3-((3-Oxo-3-(2-(2-oxoindolin-3-ylidene)hydrazinyl)propyl)(phenyl)amino)- $N^{\prime}$-(2-oxo indolin-3-ylidene)propanehydrazide (18)

Prepared from 3,3'-(phenylazanediyl)di(propanehydrazide) (7) [81] (1.33 g). Yield 60\% (1.57 g); yellow crystals; m.p. 191-192 ${ }^{\circ} \mathrm{C}$; IR (KBr) $v_{\max }\left(\mathrm{cm}^{-1}\right)$ : 1694, 1730 (C=O), 3213, 
$3305(\mathrm{NH}) ;{ }^{1} \mathrm{H}$ NMR (400 MHz, DMSO-d $): \delta 2.32\left(\mathrm{t}, 1.7 \mathrm{H}, \mathrm{J}=6.0 \mathrm{~Hz}, \mathrm{CH}_{2} \mathrm{CO}\right), 3.33-3.76$ $\left(\mathrm{m}, 6.3 \mathrm{H}, \mathrm{CH}_{2} \mathrm{CO}+\mathrm{CH}_{2} \mathrm{~N}\right), 6.55-6.69\left(\mathrm{~m}, 1.5 \mathrm{H}, \mathrm{H}_{\mathrm{Ar}}\right), 6.71-6.83\left(\mathrm{~m}, 1.5 \mathrm{H}, \mathrm{H}_{\mathrm{Ar}}\right), 6.87-6.91$ $\left(\mathrm{m}, 3 \mathrm{H}, \mathrm{H}_{\mathrm{Ar}}\right), 6.94-7.06\left(\mathrm{~m}, 2 \mathrm{H}, \mathrm{H}_{\mathrm{Ar}}\right), 7.08-7.27\left(\mathrm{~m}, 3 \mathrm{H}, \mathrm{H}_{\mathrm{Ar}}\right), 7.28-7.41\left(\mathrm{~m}, 2 \mathrm{H}, \mathrm{H}_{\mathrm{Ar}}\right), 9.06$ (s, 0.6H, NHCO), 10.76, $10.79\left(2 \mathrm{~s}, 1.4 \mathrm{H}, \mathrm{NH}_{\text {isatin }}\right), 11.09,11.21\left(2 \mathrm{~s}, 1.4 \mathrm{H}, \mathrm{NHCO}+\mathrm{NH}_{\text {isatin }}\right)$, 12.54, 12.93 (2s, 0.6H, NHCO);; ${ }^{13} \mathrm{C}$ NMR (101 MHz, DMSO-d $\left.)_{6}\right): \delta 31.61\left(\mathrm{CH}_{2} \mathrm{CO}\right), 46.95$ $\left(\mathrm{CH}_{2} \mathrm{~N}\right), 110.55,111.93,115.27,115.79,121.66,126.09,129.29,129.39,132.46,143.66,146.88$ $\left(\mathrm{C}_{\text {Ar }}\right), 164.65,169.98(\mathrm{C}=\mathrm{O})$; HRMS (ESI): $m / z$ calcd for $\mathrm{C}_{28} \mathrm{H}_{25} \mathrm{~N}_{7} \mathrm{O}_{4} 524.2047[\mathrm{M}+\mathrm{H}]^{+}$, found 524.2041 .

3-((3-Oxo-3-(2-(2-oxoindolin-3-ylidene)hydrazinyl)propyl)( $p$-tolyl)amino)- $N^{\prime}$-(2-oxo indolin-3-ylidene)propanehydrazide (19)

Prepared from 3,3'-(p-tolylazanediyl)di(propanehydrazide) (8) [81] (1.40 g). Yield 51\% (1.36 g); orange crystals; m.p. 180-181 ${ }^{\circ} \mathrm{C}$; IR (KBr) $v_{\max }\left(\mathrm{cm}^{-1}\right): 1689,1728(\mathrm{C}=\mathrm{O}), 3176$, $3212(\mathrm{NH}) ;{ }^{1} \mathrm{H}$ NMR $\left(400 \mathrm{MHz}, \mathrm{DMSO}-d_{6}\right): \delta 2.17\left(\mathrm{~s}, 3 \mathrm{H}, \mathrm{CH}_{3}\right), 2.30(\mathrm{t}, 1.5 \mathrm{H}, J=7.0 \mathrm{~Hz}$, $\left.\mathrm{CH}_{2} \mathrm{CO}\right), 3.20-3.84\left(\mathrm{~m}, 6.5 \mathrm{H}, \mathrm{CH}_{2} \mathrm{CO}+\mathrm{CH}_{2} \mathrm{~N}\right), 6.60-6.72\left(\mathrm{~m}, 1.5 \mathrm{H}, \mathrm{H}_{\mathrm{Ar}}\right), 6.72-6.83(\mathrm{~m}$, 1.5H, $\left.\mathrm{H}_{\mathrm{Ar}}\right), 6.84-6.92\left(\mathrm{~m}, 2 \mathrm{H}, \mathrm{H}_{\mathrm{Ar}}\right), 6.94-7.08\left(\mathrm{~m}, 5 \mathrm{H}, \mathrm{H}_{\mathrm{Ar}}\right), 7.72-8.28\left(\mathrm{~m}, 2 \mathrm{H}, \mathrm{H}_{\mathrm{Ar}}\right), 9.05$ (s, 0.6H, NHCO), 10.76, $10.78\left(\mathrm{~s}, 1.7 \mathrm{H}, \mathrm{NH}_{\text {isatin }}\right), 11.07$ (s, 1.2H, NHCO), 11.21 (s, 0.3H, $\left.\mathrm{NH}_{\text {isatin }}\right), 12.52,12.92(2 \mathrm{~s}, 0.2 \mathrm{H}, \mathrm{NHCO}) ;{ }^{13} \mathrm{C} \mathrm{NMR}\left(101 \mathrm{MHz}, \mathrm{DMSO}-d_{6}\right): \delta 19.92\left(\mathrm{CH}_{3}\right)$, $31.66\left(\mathrm{CH}_{2} \mathrm{CO}\right), 47.18\left(\mathrm{CH}_{2} \mathrm{~N}\right), 110.55,112.38,115.28,121.62,126.11,129.75,129.85,132.42$, $142.30,143.66,144.82\left(\mathrm{C}_{\text {Ar }}\right), 162.45,164.66(\mathrm{C}=\mathrm{O})$; HRMS (ESI): $m / z$ calcd for $\mathrm{C}_{29} \mathrm{H}_{27} \mathrm{~N}_{7} \mathrm{O}_{4}$ $538.2204[\mathrm{M}+\mathrm{H}]^{+}$, found 538.2197 .

3-((4-Methoxyphenyl)(3-oxo-3-(2-(2-oxoindolin-3-ylidene)hydrazinyl)propyl)amino)$N^{\prime}$-(2-oxoindolin-3-ylidene)propanehydrazide (20)

Prepared from 3,3'-((4-methoxyphenyl)azanediyl)di(propanehydrazide) (9) [82] (1.48 g). Yield $68 \%(1.88 \mathrm{~g})$; orange crystals; m.p. $172-173{ }^{\circ} \mathrm{C}$; IR $(\mathrm{KBr}) v_{\max }\left(\mathrm{cm}^{-1}\right): 1692$, $1723(\mathrm{C}=\mathrm{O}), 3225,3429(\mathrm{NH}) ;{ }^{1} \mathrm{H}$ NMR $\left(400 \mathrm{MHz}, \mathrm{DMSO}-d_{6}\right): \delta 3.17-3.66(\mathrm{~m}, 11 \mathrm{H}$, $\left.\mathrm{CH}_{2} \mathrm{CO}+\mathrm{CH}_{2} \mathrm{~N}+\mathrm{CH}_{3} \mathrm{O}\right), 6.60-7.01\left(\mathrm{~m}, 7 \mathrm{H}, \mathrm{H}_{\mathrm{Ar}}\right), 7.00\left(\mathrm{t}, 2 \mathrm{H}, J=8.0 \mathrm{~Hz}, \mathrm{H}_{\mathrm{Ar}}\right), 7.35(\mathrm{t}$, $\left.2 \mathrm{H}, J=8.0 \mathrm{~Hz}, \mathrm{H}_{\mathrm{Ar}}\right), 7.96-8.18\left(\mathrm{~m}, 1 \mathrm{H}, \mathrm{H}_{\mathrm{Ar}}\right), 9.04,9,78(2 \mathrm{~s}, 0.6 \mathrm{H}, \mathrm{NHCO}), 10.75,10.77,10.79$ (3s, 1.7H, $\left.\mathrm{NH}_{\text {isatin }}\right), 11.06,(\mathrm{~s}, 1.2 \mathrm{H}, \mathrm{NHCO}), 11.20$ (s, 0.3H, $\left.\mathrm{NH}_{\text {isatin }}\right), 12.51,12.93(2 \mathrm{~s}, 0.2 \mathrm{H}$, $\mathrm{NHCO}) ;{ }^{13} \mathrm{C}$ NMR (101 MHz, DMSO- $\left.d_{6}\right): \delta 39.98,40.19\left(\mathrm{CH}_{2} \mathrm{CO}\right) 46.97,47.75\left(\mathrm{CH}_{2} \mathrm{~N}\right), 55.27$ $\left(\mathrm{CH}_{3} \mathrm{O}\right), 110.53,110.05,111.09,114.85,114.94,115.27,121.61,126.09,132.41,141.41,142.28$, $143.65,151.17\left(\mathrm{C}_{\mathrm{Ar}}\right), 162.43,164.70,170.11(\mathrm{C}=\mathrm{O})$; HRMS (ESI): $m / z$ calcd for $\mathrm{C}_{29} \mathrm{H}_{27} \mathrm{~N}_{7} \mathrm{O}_{5}$ $554.2153[\mathrm{M}+\mathrm{H}]^{+}$, found 554.2146 .

3-((4-Ethoxyphenyl)(3-oxo-3-(2-(2-oxoindolin-3-ylidene)hydrazinyl)propyl)amino)- $N^{\prime}$ (2-oxoindolin-3-ylidene)propanehydrazide (21)

Prepared from 3,3'-((4-ethoxyphenyl)azanediyl)di(propanehydrazide) (10) [82] (1.7 g). Yield 44\% (270 mg); orange crystals; m.p. 178-180 ${ }^{\circ} \mathrm{C}$; IR (KBr) $v_{\max }\left(\mathrm{cm}^{-1}\right): 1693,1726$ $(\mathrm{C}=\mathrm{O}), 3240,3452(\mathrm{NH}) ;{ }^{1} \mathrm{H}$ NMR $\left(400 \mathrm{MHz}, \mathrm{DMSO}-d_{6}\right): \delta 1.28\left(\mathrm{t}, 3 \mathrm{H}, J=8.0 \mathrm{~Hz}, \mathrm{CH}_{3} \mathrm{CH}_{2} \mathrm{O}\right)$, 2.66-3.09 (m, 4H, $\left.\mathrm{CH}_{2} \mathrm{CO}\right), 3.46-3.65\left(\mathrm{~m}, 4 \mathrm{H}, \mathrm{CH}_{2} \mathrm{~N}\right), 3.90\left(\mathrm{q}, 2 \mathrm{H}, \mathrm{J}=8.0 \mathrm{~Hz}, \mathrm{CH}_{3} \mathrm{CH}_{2} \mathrm{O}\right)$, 6.63-6.77 (m, 1H, $\left.\mathrm{H}_{\mathrm{Ar}}\right), 6.78-6.83\left(\mathrm{~m}, 4 \mathrm{H}, \mathrm{H}_{\mathrm{Ar}}\right), 6.85-6.92\left(\mathrm{~m}, 2 \mathrm{H}, \mathrm{H}_{\mathrm{Ar}}\right), 6.95-7.08(\mathrm{~m}$, $\left.2 \mathrm{H}, \mathrm{H}_{\mathrm{Ar}}\right), 7.26-7.42\left(\mathrm{~m}, 2 \mathrm{H}, \mathrm{H}_{\mathrm{Ar}}\right), 8.04\left(\mathrm{~s}, 1 \mathrm{H}, \mathrm{H}_{\mathrm{Ar}}\right), 9.03$ (s, 0.3H, NHCO), 10.77, 10.79 (3s, $\left.1.8 \mathrm{H}, \mathrm{NH}_{\text {isatin }}\right), 11.08\left(\mathrm{~s}, 1.7 \mathrm{H}, \mathrm{NHCO}+\mathrm{NH}_{\text {isatin }}\right), 12.51,12.93(2 \mathrm{~s}, 0.2 \mathrm{H}, \mathrm{NHCO}) ;{ }^{13} \mathrm{C}$ NMR (101 MHz, DMSO-d $\left.)_{6}\right): \delta 14.89\left(\mathrm{CH}_{3} \mathrm{CH}_{2} \mathrm{O}\right), 31.66\left(\mathrm{CH}_{2} \mathrm{CO}\right), 47.72\left(\mathrm{CH}_{2} \mathrm{~N}\right), 63.28$ $\left(\mathrm{CH}_{3} \mathrm{CH}_{2} \mathrm{O}\right), 110.54,114.51,115.30,115.59,121.63,126.13,132.45,141.36,141.50,143.66$, $150.40\left(\mathrm{C}_{\mathrm{Ar}}\right), 164.68,170.15(\mathrm{C}=\mathrm{O})$; HRMS (ESI): $\mathrm{m} / \mathrm{z}$ calcd for $\mathrm{C}_{30} \mathrm{H}_{29} \mathrm{~N}_{7} \mathrm{O}_{5} 568.2309$ $[\mathrm{M}+\mathrm{H}]^{+}$, found 568.2308 .

3-((4-Chlorophenyl)(3-oxo-3-(2-(2-oxoindolin-3-ylidene)hydrazinyl)propyl)amino)- $N^{\prime}$ (2-oxoindolin-3-ylidene)propanehydrazide (22)

Prepared from 3,3'-((4-chlorophenyl)azanediyl)di(propanehydrazide) (11) [83] (1.58 g). Yield 36\% (1.09 g) yield, yellow crystals; m.p. 193-195 ${ }^{\circ} \mathrm{C}$; IR $(\mathrm{KBr}) v_{\max }\left(\mathrm{cm}^{-1}\right): 1689$, $1726(\mathrm{C}=\mathrm{O}), 3224,3411(\mathrm{NH}) ;{ }^{1} \mathrm{H}$ NMR $\left(400 \mathrm{MHz}, \mathrm{DMSO}-d_{6}\right): \delta 2.30(\mathrm{t}, 2 \mathrm{H}, J=8.0 \mathrm{~Hz}$, $\left.\mathrm{CH}_{2} \mathrm{CO}\right), 3.34-3.70\left(\mathrm{~m}, 6 \mathrm{H}, \mathrm{CH}_{2} \mathrm{CO}+\mathrm{CH}_{2} \mathrm{~N}\right), 6.66-6.81\left(\mathrm{~m}, 2 \mathrm{H}, \mathrm{H}_{\mathrm{Ar}}\right), 6.86-6.93\left(\mathrm{~m}, 3 \mathrm{H}, \mathrm{H}_{\mathrm{Ar}}\right)$, 6.95-7.09 (m, 2H, $\left.\mathrm{H}_{\mathrm{Ar}}\right), 7.14-7.25\left(\mathrm{~m}, 2 \mathrm{H}, \mathrm{H}_{\mathrm{Ar}}\right), 7.27-7.43\left(\mathrm{~m}, 2 \mathrm{H}, \mathrm{H}_{\mathrm{Ar}}\right), 8.09\left(\mathrm{~s}, 1 \mathrm{H}, \mathrm{H}_{\mathrm{Ar}}\right)$, 9.05 (s, 0.6H, NHCO), 10.77, 10.80 (2s, 1.7H, NH $\mathrm{Nsatin}_{\text {) }}, 11.11$ (s, 1.2H, NHCO), 11.21 (s, 0.3H, $\left.\mathrm{NH}_{\text {isatin }}\right), 12.53,12.87$ (2s, 0.2H, NHCO); ${ }^{13} \mathrm{C}$ NMR (101 MHz, DMSO-d 6 ): $\delta 31.51\left(\mathrm{CH}_{2} \mathrm{CO}\right)$, 
$46.28,47.02\left(\mathrm{CH}_{2} \mathrm{~N}\right), 110.56,113.47,113.67,115.26,121.65,126.12,128.89,128.94,129.00$, $132.49,143.68,145.77\left(\mathrm{C}_{\text {Ar }}\right), 166.62,169.84(\mathrm{C}=\mathrm{O})$; HRMS (ESI): $m / z$ calcd for $\mathrm{C}_{28} \mathrm{H}_{24} \mathrm{ClN}_{7} \mathrm{O}_{4}$ $558.1657[\mathrm{M}+\mathrm{H}]^{+}$, found 559.1706 .

\subsubsection{5-Oxo- $N^{\prime}$-(2-oxoindolin-3-ylidene)-1-( $p$-tolyl)pyrrolidine-3-carbohydrazide (26)}

Prepared from 5-oxo-1-( $p$-tolyl)pyrrolidine-3-carbohydrazide (23) [84] (1.17g) according to the synthesis procedure for compounds 12-17. Yield 89\% (1.62 g); yellow crystals; m.p. $268-269{ }^{\circ} \mathrm{C}$; IR (KBr) $v_{\max }\left(\mathrm{cm}^{-1}\right)$ : 1639, 1682, $1690(\mathrm{C}=\mathrm{O}), 3160,3282(\mathrm{NH}) ;{ }^{1} \mathrm{H}$ NMR $\left(400 \mathrm{MHz}, \mathrm{DMSO}-d_{6}\right): \delta 2.27\left(\mathrm{~s}, 3 \mathrm{H}, \mathrm{CH}_{3}\right), 2.77-2.93\left(\mathrm{~m}, 2 \mathrm{H}, \mathrm{CH}_{2} \mathrm{CO}\right), 3.90-4.27(\mathrm{~m}, 3 \mathrm{H}$, $\left.\mathrm{NCH}_{2} \mathrm{CH}+\mathrm{CH}\right), 6.90\left(\mathrm{~d}, 0.7 \mathrm{H}, J=8.0 \mathrm{~Hz}, \mathrm{H}_{\mathrm{Ar}}\right), 6.94\left(\mathrm{~d}, 0.3 \mathrm{H}, J=8.0 \mathrm{~Hz}, \mathrm{H}_{\mathrm{Ar}}\right), 6.99-7.11(\mathrm{~m}$, $\left.1 \mathrm{H}, \mathrm{H}_{\mathrm{Ar}}\right), 7.17\left(\mathrm{~d}, 2 \mathrm{H}, J=8.0 \mathrm{~Hz}, \mathrm{H}_{\mathrm{Ar}}\right), 7.34-7.42\left(\mathrm{~m}, 1 \mathrm{H}, \mathrm{H}_{\mathrm{Ar}}\right), 7.54\left(\mathrm{~d}, 2 \mathrm{H}, J=8.0 \mathrm{~Hz}, \mathrm{H}_{\mathrm{Ar}}\right)$, 10.82 (s, 0.7H, NHCO), 11.27, 11.34 (2s, $\left.1 \mathrm{H}, \mathrm{NH}_{\text {isatin }}\right), 12.59,13.08(2 \mathrm{~s}, 0.3 \mathrm{H}, \mathrm{NHCO}) ;{ }^{13} \mathrm{C}$ NMR (101 MHz, DMSO- $\left.d_{6}\right): \delta 20.43\left(\mathrm{CH}_{3}\right), 32.31\left(\mathrm{NCOCH}_{2}\right), 34.66(\mathrm{CH}), 49.78\left(\mathrm{NCH}_{2}\right)$, $110.62,111.14,115.20,119.54,121.67,126.22,129.09,133.20,136.70,142.49,143.86\left(\mathrm{C}_{\mathrm{Ar}}\right)$, 162.47, 164.57, 171.50 (C=O); HRMS (ESI): $m / z$ calcd for $\mathrm{C}_{20} \mathrm{H}_{18} \mathrm{~N}_{4} \mathrm{O}_{3} 362.1379[\mathrm{M}+\mathrm{H}]^{+}$, found 363.1453 .

3.1.5. 1-(4-Methoxyphenyl)-5-oxo- $N^{\prime}$-(2-oxoindolin-3-ylidene)pyrrolidine-3-carbo hydrazide (27)

Prepared from 1-(4-methoxyphenyl)-5-oxopyrrolidine-3-carbohydrazide (24) [85] $(1.25 \mathrm{~g})$ according to the synthesis procedure for compounds $\mathbf{1 2 - 1 7}$. Yield 82\% (1.55 g); yellow crystals; m.p. 203-204 ${ }^{\circ} \mathrm{C}$; IR (KBr) $v_{\max }\left(\mathrm{cm}^{-1}\right): 1595,1668,1689(\mathrm{C}=\mathrm{O}), 3198,3213$ $(\mathrm{NH}) ;{ }^{1} \mathrm{H}$ NMR $\left(400 \mathrm{MHz}, \mathrm{DMSO}-d_{6}\right): \delta 2.71-2.95\left(\mathrm{~m}, 2 \mathrm{H}, \mathrm{CH}_{2} \mathrm{CO}\right), 3.73\left(\mathrm{~s}, 3 \mathrm{H}, \mathrm{CH}_{3} \mathrm{O}\right)$, 3.91-4.26 (m, 3H, NCH $+\mathrm{CH}), 6.86\left(\mathrm{~d}, 2 \mathrm{H}, J=8.0 \mathrm{~Hz}, \mathrm{H}_{\mathrm{Ar}}\right), 6.89-7.01\left(\mathrm{~m}, 2 \mathrm{H}, \mathrm{H}_{\mathrm{Ar}}\right), 7.08$ $\left(\mathrm{t}, 0.6 \mathrm{H}, J=8.0 \mathrm{~Hz}, \mathrm{H}_{\mathrm{Ar}}\right), 7.14\left(\mathrm{t}, 1.4 \mathrm{H}, J=8.0 \mathrm{~Hz}, \mathrm{H}_{\mathrm{Ar}}\right), 7.36\left(\mathrm{~d}, 1 \mathrm{H}, J=8.0 \mathrm{~Hz}, \mathrm{H}_{\mathrm{Ar}}\right), 7.55$ $\left(\mathrm{d}, 1 \mathrm{H}, J=8.0 \mathrm{~Hz}, \mathrm{H}_{\mathrm{Ar}}\right), 10.82,11.26,12.59,13.09\left(4 \mathrm{~s}, 2 \mathrm{H}, \mathrm{NHCO}+\mathrm{NH}_{\text {isatin }}\right) ;{ }^{13} \mathrm{C} \mathrm{NMR}(101$ $\left.\mathrm{MHz}, \mathrm{DMSO}-d_{6}\right): \delta 32.35\left(\mathrm{COCH}_{2}\right), 34.48(\mathrm{CH}), 50.07\left(\mathrm{NCH}_{2}\right), 55.22\left(\mathrm{CH}_{3} \mathrm{O}\right), 109.97,113.84$, $115.21,117.46,121.36,126.23,127.03,132.31,138.65,142.50,155.95\left(\mathrm{C}_{\mathrm{Ar}}\right), 162.48,162.78$, $171.22(\mathrm{C}=\mathrm{O})$; HRMS (ESI): $m / z$ calcd for $\mathrm{C}_{20} \mathrm{H}_{18} \mathrm{~N}_{4} \mathrm{O}_{4} 378.1328[\mathrm{M}+\mathrm{H}]^{+}$, found 379.1400 .

3.1.6. 1-(3-Methoxyphenyl)-5-oxo- $N^{\prime}$-(2-oxoindolin-3-ylidene)pyrrolidine-3-carbo hydrazide (28)

Prepared from 1-(3-methoxyphenyl)-5-oxopyrrolidine-3-carbohydrazide (25) [86,87] (1.25 g) according to the synthesis procedure for compounds $\mathbf{1 2 - 1 7}$, just DMSO (10 mL) was used instead of methanol. Yield 85\% (1.61 g); yellow crystals; m.p. $189-190{ }^{\circ} \mathrm{C}$; IR (KBr) $v_{\max }\left(\mathrm{cm}^{-1}\right): 1615,1685,1700(\mathrm{C}=\mathrm{O}), 3191,3265(\mathrm{NH}) ;{ }^{1} \mathrm{H}$ NMR $\left(400 \mathrm{MHz}, \mathrm{DMSO}-d_{6}\right)$ : 反 2.73-2.95 (m, 2H, $\left.\mathrm{CH}_{2} \mathrm{CO}\right), 3.75\left(\mathrm{~s}, 3 \mathrm{H}, \mathrm{CH}_{3} \mathrm{O}\right), 3.93-4.25\left(\mathrm{~m}, 3 \mathrm{H}, \mathrm{NCH}_{2}+\mathrm{CH}\right), 6.73(\mathrm{~d}$, $\left.1 \mathrm{H}, J=8.0 \mathrm{~Hz}, \mathrm{H}_{\mathrm{Ar}}\right), 6.90\left(\mathrm{~d}, 0.5 \mathrm{H}, J=8.0 \mathrm{~Hz}, \mathrm{H}_{\mathrm{Ar}}\right), 6.95\left(\mathrm{~d}, 0.5 \mathrm{H}, J=8.0 \mathrm{~Hz}, \mathrm{H}_{\mathrm{Ar}}\right), 7.09(\mathrm{t}$, $\left.1 \mathrm{H}, J=8.0 \mathrm{~Hz}, \mathrm{H}_{\mathrm{Ar}}\right), 7.18\left(\mathrm{~d}, 1 \mathrm{H}, J=8.0 \mathrm{~Hz}, \mathrm{H}_{\mathrm{Ar}}\right), 7.28\left(\mathrm{t}, 1 \mathrm{H}, J=8.0 \mathrm{~Hz}, \mathrm{H}_{\mathrm{Ar}}\right), 7.31-7.43$ $\left(\mathrm{m}, 2 \mathrm{H}, \mathrm{H}_{\mathrm{Ar}}\right), 7.51-7.66\left(\mathrm{~m}, 0.5 \mathrm{H}, \mathrm{H}_{\mathrm{Ar}}\right), 8.13\left(\mathrm{~s}, 0.5 \mathrm{H}, \mathrm{H}_{\mathrm{Ar}}\right), 10.82(\mathrm{~s}, 0.5 \mathrm{H}, \mathrm{NHCO}), 11.27$ (s, 0.5H, $\left.\mathrm{NH}_{\text {isatin }}\right), 11.37$ (s, $\left.0.5 \mathrm{H}, \mathrm{NH}_{\text {isatin }}\right), 12.59,13.07$ (2s, 0.5H, NHCO); ${ }^{13} \mathrm{C} \mathrm{NMR}(101$ $\left.\mathrm{MHz}, \mathrm{DMSO}-d_{6}\right): \delta 32.24\left(\mathrm{COCH}_{2}\right), 34.87(\mathrm{CH}), 49.86\left(\mathrm{NCH}_{2}\right), 55.12\left(\mathrm{CH}_{3} \mathrm{O}\right), 105.61,109.56$, $110.63,111.15,111.69,115.20,119.77,121.68,122.58,129.51,131.67,140.28,143.86\left(\mathrm{C}_{\mathrm{Ar}}\right)$, $159.45,162.48,171.87(\mathrm{C}=\mathrm{O})$; HRMS (ESI): $m / z$ calcd for $\mathrm{C}_{20} \mathrm{H}_{18} \mathrm{~N}_{4} \mathrm{O}_{4} 378.1328[\mathrm{M}+\mathrm{H}]^{+}$, found 379.1400 .

3.1.7. 2-(2-(1-(4-Chlorophenyl)-5-oxopyrrolidin-3-yl)-1H-benzo[d]imidazol-1-yl)-N'-(2oxoindolin-3-ylidene)acetohydrazide (30)

Prepared from 2-(2-(1-(4-chlorophenyl)-5-oxopyrrolidin-3-yl)-1H-benzo[d]imidazol-1yl)acetohydrazide (29) [34] (1.92 g) according to the synthesis procedure for compounds 12-17. Yield 55\% (1.40 g); orange crystals; m.p. $216-217^{\circ} \mathrm{C}$; IR (KBr) $v_{\max }\left(\mathrm{cm}^{-1}\right)$ : 1616 , 1695, 1727 (C=O), 3269, $3340(\mathrm{NH}) ;{ }^{1} \mathrm{H}$ NMR (400 MHz, DMSO-d $\left.)_{6}\right): \delta 2.70-3.09(\mathrm{~m}, 2 \mathrm{H}$, $\left.\mathrm{CH}_{2} \mathrm{CO}\right), 3.33\left(\mathrm{~s}, 2 \mathrm{H}, \mathrm{NCOCH}_{2}\right), 3.86-3.91\left(\mathrm{~m}, 2 \mathrm{H}, \mathrm{NCH}_{2} \mathrm{CH}\right), 5.29(\mathrm{~s}, 1 \mathrm{H}, \mathrm{CH}), 6.59(\mathrm{~d}, 2 \mathrm{H}$, $\left.J=8.0 \mathrm{~Hz}, \mathrm{H}_{\mathrm{Ar}}\right), 6.73\left(\mathrm{~d}, 2 \mathrm{H}, J=8.0 \mathrm{~Hz}, \mathrm{H}_{\mathrm{Ar}}\right), 6.89\left(\mathrm{~d}, 1 \mathrm{H}, J=8.0 \mathrm{~Hz}, \mathrm{H}_{\mathrm{Ar}}\right), 6.92-7.27(\mathrm{~m}$, 
$\left.2 \mathrm{H}, \mathrm{H}_{\mathrm{Ar}}\right), 7.36\left(\mathrm{t}, 2 \mathrm{H}, J=8.0 \mathrm{~Hz}, \mathrm{H}_{\mathrm{Ar}}\right), 7.43-7.56\left(\mathrm{~m}, 1 \mathrm{H}, \mathrm{H}_{\mathrm{Ar}}\right), 7.66\left(\mathrm{~d}, 0.5 \mathrm{H}, J=8.0 \mathrm{~Hz}, \mathrm{H}_{\mathrm{Ar}}\right)$, $7.72\left(\mathrm{~d}, 0.5 \mathrm{H}, J=8.0 \mathrm{~Hz}, \mathrm{H}_{\mathrm{Ar}}\right), 7.81-8.32\left(\mathrm{~m}, 1 \mathrm{H}, \mathrm{H}_{\mathrm{Ar}}\right), 10.78,10.88\left(2 \mathrm{~s}, 1 \mathrm{H}, \mathrm{NH}_{\text {isatin }}\right), 11.14$, 11.24 (2s, 1H, NHCO); ${ }^{13} \mathrm{C}$ NMR (101 MHz, DMSO-d 6$): \delta 28.47(\mathrm{CH}), 39.98\left(\mathrm{CH}_{2} \mathrm{CO}\right), 43.16$ $\left(\mathrm{COCH}_{2}\right), 52.09\left(\mathrm{NCH}_{2} \mathrm{CH}\right), 110.55,113.41,115.28,115.45,119.87,120.93,121.62,125.98$, $128.59,130.48,132.4,132.45,136.22,137.33,140.73,142.61,143.63,155.12\left(\mathrm{C}_{\mathrm{Ar}}\right), 160.24$, 164.63, $170.08(\mathrm{C}=\mathrm{O})$; HRMS (ESI): $m / z$ calcd for $\mathrm{C}_{27} \mathrm{H}_{21} \mathrm{ClN}_{6} \mathrm{O}_{3} 536.1343[\mathrm{M}+\mathrm{H}+\mathrm{Na}]^{+}$, found 536.1645 .

3.1.8. $\left(N^{\prime}, N^{\prime \prime \prime}\right)-3,3^{\prime}-\left(\left(\right.\right.$ methylenebis(4,1-phenylene))bis(azanediyl))bis( $N^{\prime}$-(2-oxoindolin-3ylidene)propanehydrazide) (32)

Prepared from 3,3'-((methylenebis(4,1-phenylene))bis(azanediyl))di(propanehydrazide) (31) [88] (0.85 g) according to the synthesis procedure for compounds 18-22. Yield 42\% (380 mg); orange crystals; m.p. $166-167^{\circ} \mathrm{C}$; IR (KBr) $v_{\max }\left(\mathrm{cm}^{-1}\right)$ : 1692, 1730 (C=O), 3160, 3225, $3352(\mathrm{NH}) ;{ }^{1} \mathrm{H}$ NMR (400 MHz, DMSO-d 6 ): $\delta 2.59-3.43\left(\mathrm{~m}, 8 \mathrm{H}, \mathrm{CH}_{2} \mathrm{CO}+\mathrm{CH}_{2} \mathrm{NH}\right)$, $3.62\left(\mathrm{~s}, 2 \mathrm{H}, \mathrm{CH}_{2}\right), 5.53\left(\mathrm{~s}, 2 \mathrm{H}, \mathrm{CH}_{2} \mathrm{NH}\right), 6.39-6.68\left(\mathrm{~m}, 4 \mathrm{H}, \mathrm{H}_{\mathrm{Ar}}\right), 6.73-7.13\left(\mathrm{~m}, 8 \mathrm{H}, \mathrm{H}_{\mathrm{Ar}}\right)$, $7.35\left(\mathrm{t}, 2 \mathrm{H}, \mathrm{J}=8.0 \mathrm{~Hz}, \mathrm{H}_{\mathrm{Ar}}\right), 7.43-8.24\left(\mathrm{~m}, 2 \mathrm{H}, \mathrm{H}_{\mathrm{Ar}}\right), 9.85,10.77,11.03,11.11,11.23,12.54$, 12.97 (7s, 4H, NHCO+NH isatin $) ;{ }^{13} \mathrm{C} \mathrm{NMR}\left(101 \mathrm{MHz}, \mathrm{DMSO}-d_{6}\right): \delta 23.22\left(\mathrm{CH}_{2} \mathrm{CO}\right), 39.98$ $\left(\mathrm{CH}_{2}\right), 50.97\left(\mathrm{CH}_{2} \mathrm{NH}\right), 110.54,112.37,115.28,121.62,126.01,129.07,129.13,132.42,142.30$, 143.63, $146.45\left(\mathrm{C}_{\mathrm{Ar}}\right), 162.48,168.56(\mathrm{C}=\mathrm{O})$; HRMS (ESI): $m / z$ calcd for $\mathrm{C}_{35} \mathrm{H}_{32} \mathrm{~N}_{8} \mathrm{O}_{4} 629.2626$ $[\mathrm{M}+\mathrm{H}]^{+}$, found 629.2619 .

3.1.9. Methyl 1-[4-(\{4-[4-(methoxycarbonyl)-2-oxopyrrolidine-1-il]phenyl\}methyl)phenyl]5-oxopyrrolidine-3-carboxylate (33)

A mixture of 1,1'-(methylenebis(4,1-phenylene))bis(5-oxopyrrolidine-3-carboxylic acid) $18 \mathrm{~g}, 43 \mathrm{mmol})$, methanol $(200 \mathrm{~mL})$, and sulfuric acid $(10 \mathrm{~mL})$ was heated at reflux for $1 \mathrm{~h}$ (until formation of precipitate). Precipitate was filtered off and recrystallized from DMF $/ \mathrm{H}_{2} \mathrm{O}$ mixture. Yield $47 \%$ (8.95 g); white crystals; m. p. $166-167^{\circ} \mathrm{C}$; IR $(\mathrm{KBr}) v_{\max }$ $\left(\mathrm{cm}^{-1}\right): 1688,1727(\mathrm{C}=\mathrm{O}) ;{ }^{1} \mathrm{H}$ NMR $\left(400 \mathrm{MHz}, \mathrm{DMSO}-d_{6}\right): \delta 2.67-2.85\left(\mathrm{~m}, 4 \mathrm{H}, \mathrm{CH}_{2} \mathrm{CO}\right)$, 3.41-3.48 (m, 2H, CH), $3.67\left(\mathrm{~s}, 6 \mathrm{H}, \mathrm{CH}_{3}\right), 3.89\left(\mathrm{~s}, 2 \mathrm{H}, \mathrm{CH}_{2}\right), 3.92-4.06\left(\mathrm{~m}, 4 \mathrm{H}, \mathrm{CH}_{2} \mathrm{~N}\right), 7.21$ $\left(\mathrm{d}, 4 \mathrm{H}, J=8.8 \mathrm{~Hz}, \mathrm{H}_{\mathrm{Ar}}\right), 7.54\left(\mathrm{~d}, 4 \mathrm{H}, J=8.8 \mathrm{~Hz}, \mathrm{H}_{\mathrm{Ar}}\right) ;{ }^{13} \mathrm{C}$ NMR $\left(101 \mathrm{MHz}, \mathrm{DMSO}-d_{6}\right): 34.95$ $\left(\mathrm{CH}_{2} \mathrm{CO}\right), 34.98(\mathrm{CH}), 39.84\left(\mathrm{CH}_{2}\right), 49.77\left(\mathrm{NCH}_{2}\right), 52.19\left(\mathrm{CH}_{3}\right), 119.67,128.88,137.10,137.25$ $\left(\mathrm{C}_{\text {Ar }}\right), 171.35,173.15(\mathrm{C}=\mathrm{O})$; HRMS (ESI): $m / z$ calcd for $\mathrm{C}_{25} \mathrm{H}_{26} \mathrm{~N}_{2} \mathrm{O}_{6} 468.1856\left[\mathrm{M}+\mathrm{H}_{2} \mathrm{O}\right]^{+}$, found 468.2130 .

3.1.10. 1,1'-(Methylenebis(4,1-phenylene))bis(5-oxopyrrolidine-3-carbohydrazide) (34)

To a solution of methyl 1-[4-(\{4-[4-(methoxycarbonyl)-2-oxopyrrolidine-1-il]phenyl $\}$ methyl)phenyl]-5-oxopyrrolidine-3-carboxylate (33) (9 g, $20 \mathrm{mmol})$ in hot DMSO (30 $\mathrm{mL})$, hydrazine hydrate $(3.5 \mathrm{~mL}, 72 \mathrm{mmol})$ was added. Already after 10 min crystals started forming. The reaction mixture was cooled down. The precipitate was filtered off, washed with diethyl ether, and recrystallized from $\mathrm{DMF} / \mathrm{H}_{2} \mathrm{O}$ mixture. Yield $67 \%$ (6.05 g); white crystals; m.p. $>300{ }^{\circ} \mathrm{C}$ decomposes. IR $(\mathrm{KBr}) v_{\max }\left(\mathrm{cm}^{-1}\right): 1644,1728(\mathrm{C}=\mathrm{O}), 2820-3433$ $(\mathrm{NH}) ;{ }^{1} \mathrm{H}$ NMR $\left(400 \mathrm{MHz}, \mathrm{DMSO}-d_{6}\right): \delta 2.57-2.89\left(\mathrm{~m}, 4 \mathrm{H}, \mathrm{CH}_{2} \mathrm{CO}\right), 3.39(\mathrm{~s}, 2 \mathrm{H}, \mathrm{CH}), 3.78$ $4.13\left(\mathrm{~m}, 6 \mathrm{H}, \mathrm{CH}_{2} \mathrm{~N}+\mathrm{CH}_{2}\right), 7.21\left(\mathrm{~d}, 4 \mathrm{H}, J=7.2 \mathrm{~Hz}, \mathrm{H}_{\mathrm{Ar}}\right), 7.53\left(\mathrm{~d}, 4 \mathrm{H}, J=7.2 \mathrm{~Hz}, \mathrm{H}_{\mathrm{Ar}}\right), 9.79$ (s, $\left.4 \mathrm{H}, \mathrm{NH}_{2}\right), 11.35(\mathrm{~s}, 2 \mathrm{H}, \mathrm{NH}) ;{ }^{13} \mathrm{C} \mathrm{NMR}\left(101 \mathrm{MHz}, \mathrm{DMSO}-d_{6}\right): \delta 33.97\left(\mathrm{CH}_{2} \mathrm{CO}\right), 35.41(\mathrm{CH})$, $39.8\left(\mathrm{CH}_{2}\right), 39.94\left(\mathrm{CH}_{2}\right), 50.33\left(\mathrm{NCH}_{2}\right), 119.85,129.06,137.22,137.48\left(\mathrm{C}_{\mathrm{Ar}}\right), 171.49,172.03$ $(\mathrm{C}=\mathrm{O})$; Anal. Calcd for $\mathrm{C}_{23} \mathrm{H}_{26} \mathrm{~N}_{6} \mathrm{O}_{4}$ : C, 61.31; $\mathrm{H}, 5.82 ; \mathrm{N}, 18.66$, found: $\mathrm{C}, 61.47$; $\mathrm{H}, 5.67$; $\mathrm{N}, 18.83 \%$.

3.1.11. $\left(N^{\prime}, N^{\prime \prime \prime}\right)$-1,1'-(methylenebis(4,1-phenylene))bis(5-oxo- $N^{\prime}$-(2-oxoindolin-3-ylidene) pyrrolidine-3-carbohydrazide) (35)

Prepared from 1,1'-(methylenebis(4,1-phenylene))bis(5-oxopyrrolidine-3-carbo hydrazide) (34) (2.25 g) according to the synthesis procedure for compounds 18-22. Yield 54\% (1.9 g); yellow crystals; m.p. $191-192{ }^{\circ} \mathrm{C}$; IR (KBr) $v_{\max }\left(\mathrm{cm}^{-1}\right)$ : 1665, 1694, 1734 $(\mathrm{C}=\mathrm{O}), 3398,3451(\mathrm{NH}) ;{ }^{1} \mathrm{H}$ NMR $\left(400 \mathrm{MHz}, \mathrm{DMSO}-d_{6}\right): \delta 2.54-2.64\left(\mathrm{~m}, 3 \mathrm{H}, \mathrm{CH}_{2} \mathrm{CO}\right)$, 
3.44 (quint, $1 \mathrm{H}, \mathrm{J}=8.0 \mathrm{~Hz}, \mathrm{CH}), 3.67\left(\mathrm{~s}, 2 \mathrm{H}, \mathrm{CH}_{2}\right), 3.89-4.16\left(\mathrm{~m}, 6 \mathrm{H}, \mathrm{NCH}_{2}+\mathrm{CH}_{2} \mathrm{CO}+\mathrm{CH}\right)$, 6.87-6.97 (m, 1.5H, $\left.\mathrm{H}_{\mathrm{Ar}}\right), 7.02-7.12\left(\mathrm{~m}, 1.5 \mathrm{H}, \mathrm{H}_{\mathrm{Ar}}\right), 7.21\left(\mathrm{~d}, 4 \mathrm{H}, J=8.0 \mathrm{~Hz}, \mathrm{H}_{\mathrm{Ar}}\right), 7.37(\mathrm{t}$, $\left.1 \mathrm{H}, J=8.0 \mathrm{~Hz}, \mathrm{H}_{\mathrm{Ar}}\right), 7.45-7.66\left(\mathrm{~m}, 8 \mathrm{H}, \mathrm{H}_{\mathrm{Ar}}\right), 10.19,10.82,11.03,11.26,12.59,13.07$ (6s, $\left.4 \mathrm{H}, \mathrm{NHCO}+\mathrm{NH}_{\text {isatin }}\right) ;{ }^{13} \mathrm{C}$ NMR $\left(101 \mathrm{MHz}, \mathrm{DMSO}-d_{6}\right): \delta 32.34\left(\mathrm{CH}_{2} \mathrm{CO}\right), 34.94,34.96$ $(\mathrm{CH}), 39.83,40.43\left(\mathrm{CH}_{2}\right), 49.75,52.15\left(\mathrm{NCH}_{2}\right), 111.13,112.19,117.82,119.65,120.85,122.57$, $122.75,124.68,128.84,131.65,137.08,137.14,137.22,138.36,142.49,150.71\left(\mathrm{C}_{\mathrm{Ar}}\right), 159.37$, 162.47, 171.30, $173.10(\mathrm{C}=\mathrm{O})$; HRMS (ESI): $m / z$ calcd for $\mathrm{C}_{39} \mathrm{H}_{32} \mathrm{~N}_{8} \mathrm{O}_{6} 712.2761[\mathrm{M}+4 \mathrm{H}]^{+}$, found 712.234 .

\subsubsection{5-Oxo-1-(4-(phenylamino)phenyl)pyrrolidine-3-carboxylic acid (36)}

To a solution of itaconic acid $(26 \mathrm{~g}, 0.2 \mathrm{~mol})$ in water $(250 \mathrm{~mL}), 4$-aminodiphenylamine $(36.80 \mathrm{~g}, 0.2 \mathrm{~mol})$ was added and the reaction mixture was heated at reflux for $24 \mathrm{~h}$. Precipitate was filtered off and dissolved in an aqueous $20 \% \mathrm{NaOH}$ solution. The solution was heated at reflux with activated carbon for $5 \mathrm{~min}$, filtered, and acidified with conc. $\mathrm{HCl}$ to $\mathrm{pH}$ 2. Yield $87 \%$ (51.30 g); grey crystals; m.p. $168-169{ }^{\circ} \mathrm{C}$; IR $(\mathrm{KBr}) v_{\max }\left(\mathrm{cm}^{-1}\right)$ : 1677, 1696 (C=O), $3284(\mathrm{NH}) ;{ }^{1} \mathrm{H}$ NMR (400 MHz, DMSO-d $): \delta 2.60-2.81\left(\mathrm{~m}, 2 \mathrm{H}, \mathrm{CH}_{2} \mathrm{CO}\right)$; 3.29-3.37 (m, 1H, CH), 3.87-4.05 (m, 2H, NCH $), 6.79\left(\mathrm{t}, 1 \mathrm{H}, J=7.2 \mathrm{~Hz}, \mathrm{H}_{\mathrm{Ar}^{\prime} 4}\right), 6.98-7.12$ $\left(\mathrm{m}, 4 \mathrm{H}, \mathrm{H}_{\mathrm{Ar}} \mathrm{Ar}^{\mathrm{c}}\right), 7.21\left(\mathrm{t}, 2 \mathrm{H}, J=7.2 \mathrm{~Hz}, \mathrm{H}_{\mathrm{Ar}}{ }^{3}, 5\right), 7.49\left(\mathrm{~d}, 2 \mathrm{H}, J=8.8 \mathrm{~Hz}, \mathrm{H}_{\mathrm{Ar} 3,5}\right), 8.17(\mathrm{~s}, 1 \mathrm{H}$, $\mathrm{NH}), 12.76(\mathrm{~s}, 1 \mathrm{H}, \mathrm{OH}) ;{ }^{13} \mathrm{C}$ NMR $\left(101 \mathrm{MHz}, \mathrm{DMSO}-d_{6}\right): \delta 35.08\left(\mathrm{CH}_{2} \mathrm{CO}\right), 35.25(\mathrm{CH}), 50.26$ $\left(\mathrm{NCH}_{2}\right), 116.23,117.18,119.43,121.08,129.22,131.76,139.85,143.66\left(\mathrm{C}_{\text {Ar }}\right), 171.15,174.39$ $(\mathrm{C}=\mathrm{O})$; HRMS (ESI): $m / z$ calcd for $\mathrm{C}_{17} \mathrm{H}_{16} \mathrm{~N}_{2} \mathrm{O}_{3} 297.1240[\mathrm{M}+\mathrm{H}]^{+}$, found 297.1242.

\subsubsection{Methyl 5-oxo-1-(4-(phenylamino)phenyl)pyrrolidine-3-carboxylate (37)}

To a solution of 5-oxo-1-(4-(phenylamino)phenyl)pyrrolidine-3-carboxylic acid (36) $(51 \mathrm{~g}, 0.17 \mathrm{~mol})$ in methanol $(120 \mathrm{~mL}), \mathrm{H}_{2} \mathrm{SO}_{4}(2 \mathrm{~mL})$ was added dropwise. The reaction mixture was heated at reflux for $24 \mathrm{~h}$. Aqueous $15 \% \mathrm{Na}_{2} \mathrm{CO}_{3}$ solution was added until $\mathrm{pH} 8$, and the precipitate was filtered off and dried. Yield $72 \%$ (38.58 g); grey crystals; m.p. 80-81 ${ }^{\circ} \mathrm{C}$; IR (KBr) $v_{\max }\left(\mathrm{cm}^{-1}\right): 1651,1687(\mathrm{C}=\mathrm{O}), 3213(\mathrm{NH}) ;{ }^{1} \mathrm{H}$ NMR $(400 \mathrm{MHz}$, DMSO- $\left.d_{6}\right): \delta 2.64-2.82\left(\mathrm{~m}, 2 \mathrm{H}, \mathrm{CH}_{2} \mathrm{CO}\right), 3.40-3.50(\mathrm{~m}, 1 \mathrm{H}, \mathrm{CH}), 3.68\left(\mathrm{~s}, 3 \mathrm{H}, \mathrm{CH}_{3}\right), 3.90-4.06$ $\left(\mathrm{m}, 2 \mathrm{H}, \mathrm{CH}_{2} \mathrm{~N}\right), 6.79\left(\mathrm{t}, 1 \mathrm{H}, J=8.0 \mathrm{~Hz}, \mathrm{H}_{\mathrm{Ar}^{\prime} 4}\right), 6.99-7.12\left(\mathrm{~m}, 4 \mathrm{H}, \mathrm{H}_{\mathrm{Ar}+\mathrm{Ar}^{\prime}}\right), 7.21(\mathrm{t}, 2 \mathrm{H}$, $\left.J=8.0 \mathrm{~Hz}, \mathrm{H}_{\mathrm{Ar} 3,5}\right), 7.48\left(\mathrm{~d}, 2 \mathrm{H}, J=8.4 \mathrm{~Hz}, \mathrm{H}_{\mathrm{Ar} 3,5}\right), 8.14(\mathrm{~s}, 1 \mathrm{H}, \mathrm{NH}) ;{ }^{13} \mathrm{C} \mathrm{NMR}(101 \mathrm{MHz}$, DMSO- $\left.d_{6}\right): \delta 34.87\left(\mathrm{CH}_{2} \mathrm{CO}\right), 35.00(\mathrm{CH}), 50.02\left(\mathrm{NCH}_{2}\right), 52.20\left(\mathrm{CH}_{3}\right), 116.25,117.17,119.44$, 121.12, 129.21, 131.62, 139.92, $143.62\left(\mathrm{C}_{\mathrm{Ar}}\right), 170.87,173.26(\mathrm{C}=\mathrm{O})$; HRMS (ESI): $m / z$ calcd for $\mathrm{C}_{18} \mathrm{H}_{18} \mathrm{~N}_{2} \mathrm{O}_{3} 311.1396[\mathrm{M}+\mathrm{H}]^{+}$, found 311.1404 .

\subsubsection{5-Oxo-1-(4-(phenylamino)phenyl)pyrrolidine-3-carbohydrazide (38)}

To a solution of methyl 5-oxo-1-(4-(phenylamino)phenyl)pyrrolidine-3-carboxylate (37) $(10 \mathrm{~g}, 32 \mathrm{mmol})$ in propan-2-ol $(25 \mathrm{~mL})$, hydrazine hydrate $(3 \mathrm{~mL}, 96 \mathrm{mmol})$ was added dropwise, and the reaction mixture was heated at reflux for $22 \mathrm{~h}$. Precipitate was filtered off and recrystallized from propan-2-ol. Yield $82 \%(8.21 \mathrm{~g})$; grey crystals; m.p. $163-164{ }^{\circ} \mathrm{C}$; IR (KBr) $v_{\max }\left(\mathrm{cm}^{-1}\right)$ : 3299-3028 (NH); 1680, $1644(\mathrm{C}=\mathrm{O}) ;{ }^{1} \mathrm{H}$ NMR (400 MHz, DMSO- $\left.d_{6}\right)$ : 反 2.55-2.72 (m, 2H, CH $\left.{ }_{2} \mathrm{CO}\right), 3.090-3.21(\mathrm{~m}, 1 \mathrm{H}, \mathrm{CH}), 3.77-3.85\left(\mathrm{~m}, 1 \mathrm{H}, \mathrm{CH}_{2} \mathrm{~N}\right), 3.89-3.97$ $\left(\mathrm{m}, 1 \mathrm{H}, \mathrm{CH}_{2} \mathrm{~N}\right), 4.31,4.47\left(2 \mathrm{~s}, 2 \mathrm{H}, \mathrm{NHNH}_{2}\right), 6.79\left(\mathrm{t}, 1 \mathrm{H}, J=7.2 \mathrm{~Hz}, \mathrm{H}_{\mathrm{Ar}^{\prime} 4}\right), 6.99-7.12(\mathrm{~m}$, $\left.4 \mathrm{H}, \mathrm{H}_{\mathrm{Ar} 2,6}+\mathrm{H}_{\mathrm{Ar} 2,6}\right), 7.21\left(\mathrm{t}, 2 \mathrm{H}, J=7.2 \mathrm{~Hz}, \mathrm{H}_{\mathrm{Ar} 3,5}\right), 7.49\left(\mathrm{~d}, 2 \mathrm{H}, J=8.8 \mathrm{~Hz}, \mathrm{H}_{\mathrm{Ar} 3,5}\right), 8.13$ (s, 1H, NH), $9.27\left(\mathrm{~s}, 1 \mathrm{H}, \mathrm{NHNH}_{2}\right) ;{ }^{13} \mathrm{C} \mathrm{NMR}\left(101 \mathrm{MHz}, \mathrm{DMSO}-d_{6}\right): \delta 34.16(\mathrm{CH}), 35.57$ $\left(\mathrm{NCOCH}_{2}\right), 50.92\left(\mathrm{NCH}_{2} \mathrm{CH}\right), 116.21,117.19,119.38,120.97,121.17,121.22,129.17,131.80$, 139.77, 143.66 ( $\left.\mathrm{C}_{\text {Ar }}\right), 171.34,171.63(\mathrm{C}=\mathrm{O})$; HRMS (ESI): $m / z$ calcd for $\mathrm{C}_{17} \mathrm{H}_{18} \mathrm{~N}_{4} \mathrm{O}_{2} 311.1508$ $[\mathrm{M}+\mathrm{H}]^{+}$, found 311.1503 .

3.1.15. 5-Oxo- $N^{\prime}$-(2-oxoindolin-3-ylidene)-1-(4-(phenylamino)phenyl)pyrrolidine-3carbohydrazide (39)

Prepared from 5-oxo-1-(4-(phenylamino)phenyl)pyrrolidine-3-carbohydrazide (38) according to the synthesis procedure for compounds 12-17. Yield 89\% (1.95 g); yellow crystals; m.p. $243-244{ }^{\circ} \mathrm{C}$; IR (KBr) $v_{\max }\left(\mathrm{cm}^{-1}\right)$ : 1640, 1695, $1725(\mathrm{C}=\mathrm{O}), 3175,3282,3310$ 
$(\mathrm{NH}) ;{ }^{1} \mathrm{H}$ NMR (400 MHz, DMSO-d $): \delta 2.74-2.94\left(\mathrm{~m}, 2 \mathrm{H}, \mathrm{CH}_{2} \mathrm{CO}\right), 3.37$ (s, 1H, CH), 3.96-4.18 (m, 2H, NCH $), 6.79\left(\mathrm{t}, 1 \mathrm{H}, J=8.0 \mathrm{~Hz}, \mathrm{H}_{\mathrm{Ar}}\right), 6.90-6.96\left(\mathrm{~m}, 1 \mathrm{H}, \mathrm{H}_{\mathrm{Ar}}\right), 7.03-7.10(\mathrm{~m}$, $\left.5 \mathrm{H}, \mathrm{H}_{\mathrm{Ar}}\right), 7.21\left(\mathrm{t}, 2 \mathrm{H}, J=8.0 \mathrm{~Hz}, \mathrm{H}_{\mathrm{Ar}}\right), 7.36-7.62\left(\mathrm{~m}, 4 \mathrm{H}, \mathrm{H}_{\mathrm{Ar}}\right), 8.14(\mathrm{~s}, 1 \mathrm{H}, \mathrm{NH}), 10.83(\mathrm{~s}$, $0.7 \mathrm{H}, \mathrm{NHCO}), 11.27,11.37\left(\mathrm{~s}, 1 \mathrm{H}, \mathrm{NH}_{\text {isatin }}\right), 12.60,13.09$ (2s, 0.3H, NHCO); ${ }^{13} \mathrm{C}$ NMR $(101$ $\left.\mathrm{MHz}, \mathrm{DMSO}-d_{6}\right): \delta 34.50(\mathrm{CH}), 35.47\left(\mathrm{NCOCH}_{2}\right), 50.01\left(\mathrm{NCH}_{2} \mathrm{CH}\right), 110.63,111.14,115.21$, 116.23, 117.18, 119.40, 120.83, 121.17, 121.22, 121.69, 122.57, 126.13, 129.17, 131.66, 131.71, $139.89,139.92,142.49,143.64,143.86\left(\mathrm{C}_{\mathrm{Ar}}\right), 162.48,164.56,171.10(\mathrm{C}=\mathrm{O}) ;$ HRMS $(\mathrm{ESI}): \mathrm{m} / z$ calcd for $\mathrm{C}_{25} \mathrm{H}_{21} \mathrm{~N}_{5} \mathrm{O}_{3} 440.1723[\mathrm{M}+\mathrm{H}]^{+}$, found 440.1718 .

\subsection{Pharmacology \\ 3.2.1. Anticancer Activity \\ Cell Culturing}

The human malignant melanoma cell line A375 and human colon adenocarcinoma cell line HT-29 were obtained from the American Type Culture Collection (ATCC, Manassas, VA, USA). Human foreskin fibroblasts (HF) CRL-4001 were originally obtained from ATCC and kindly provided by Prof. Helder Santos (University of Helsinki, Finland). A375, HT-29, and HF were cultured in Dulbecco's modified eagle's GlutaMAX medium (Gibco (Carlsbad, CA, USA)). Medium was supplemented with 10,000 U/mL penicillin, $10 \mathrm{mg} / \mathrm{mL}$ streptomycin (Gibco), and 10\% fetal bovine serum (Gibco). Cell cultures were grown at $37{ }^{\circ} \mathrm{C}$ in a humidified atmosphere containing $5 \% \mathrm{CO}_{2}$. They were used until the passage of $20 \mathrm{~min}$.

\section{Cell Viability Assay}

The effects of the isatin derivatives on cell viability were studied using 3-(4,5-dimethyl thiazol-2-yl)-2,5-diphenyltetrazolium bromide (MTT; Sigma-Aldrich Co., St Louis, MO, USA) assays, as described elsewhere [35,89]. Briefly, A375, HT-29, and HF cells were seeded in 96-well plates (Corning) in triplicate repeats at a volume of $100 \mu \mathrm{L}\left(5 \times 10^{3}\right.$ cells / well). After $24 \mathrm{~h}$ of incubation, the cells were treated with $100 \mu \mathrm{M}$ of tested compounds. After $72 \mathrm{~h}$, the cells were exposed to the reagent MTT for $4 \mathrm{~h}$. Then the medium was aspirated and the formed formazan crystals were dissolved in $100 \mu \mathrm{L}$ DMSO (Sigma-Aldrich Co.). The absorbance was measured at 570 and $630 \mathrm{~nm}$ using a multi-detection microplate reader. The compound's effect on cell viability was calculated using a formula:

$$
\text { Relative cell viability }(\%)=\frac{A-A_{0}}{A_{N C}-A_{0}}
$$

where $A-$ mean of absorbance of tested compound; $A_{0}$-mean of absorbance of blank (no cells, positive control); $A_{N C}$-mean of absorbance of negative control (only cells, no treatment).

The $\mathrm{EC}_{50}$ values of the most active compounds, $\mathbf{1 7}, \mathbf{1 8}, \mathbf{2 0}$, and $\mathbf{3 5}$, were established by the same MTT procedure; only the compound serial dilutions from 50 to $1.56 \mu \mathrm{M}$ were made in a medium and added to the cells in triplicate repeats. Each $\mathrm{EC}_{50}$ value, which represents the concentration of a compound causing a 50\% reduction of cancer cells' metabolic activity, has been calculated using the Hill equation.

\section{Colony Formation Assay}

Clonogenic assays were used to evaluate the inhibitory effects of the most active compounds, 17, 18, 20, and 35, on cell survival and proliferation via forming colonies, as described elsewhere [90]. Briefly, melanoma A375 and colon adenocarcinoma HT-29 cells were seeded into 12-well plates in triplicate repeats $\left(2 \times 10^{2}\right.$ cells / well $)$ and grown in the previously described cell culture medium at $37{ }^{\circ} \mathrm{C}$ in a humidified atmosphere containing $5 \% \mathrm{CO}_{2}$. After $24 \mathrm{~h}$, the fresh media containing compounds 17, 18, 20, and 35 at concentrations representing $50 \%$ of calculated $\mathrm{EC}_{50}$ values were added to cells. Then, cells were incubated at $37{ }^{\circ} \mathrm{C}$ in a humidified atmosphere containing $5 \% \mathrm{CO}_{2}$ for the next 7-8 days. Cells treated with medium containing 0.5\% DMSO served as a negative control. After incubation, the colonies were stained with a $0.1 \%$ crystal violet (Sigma-Aldrich Co.) 
solution. First, the media were removed from cells, and the cells were washed with sterile PBS. Then, the cells were fixed in a $4 \%$ formaldehyde (Thermo Scientific) solution and washed with PBS two times to remove the fixative, and stained with crystal violet for $20 \mathrm{~min}$. After the stain had been removed, the remaining stain residues were washed three times with sterile water. The plates were dried overnight and imaged with the SYNGENE G:BOX gel doc system, using Gen Sys software. Quantification was performed using Gene tools software.

\section{Compound Activity in Spheroids}

Cancer cell spheroids were formed by using the magnetic 3D Bioprinting method, as described elsewhere [91]. Briefly, melanoma (A375) and adenocarcinoma (HT-29) cells and human fibroblasts at 70\% confluency in a 6-well plate were incubated with Nanoshuttle (n3D Biosciences, Inc.) for $7-8 \mathrm{~h}$ at $37{ }^{\circ} \mathrm{C}$ in a humidified atmosphere containing $5 \% \mathrm{CO}_{2}$. After nanoparticles were taken up by cells, they were trypsinized, centrifuged, and seeded into ultra-low attachment 96-well plate in a volume of $100 \mu \mathrm{L}\left(1.5 \times 10^{3}\right.$ cancer cells and $1.5 \times 10^{3}$ human fibroblasts/well). The plate was placed on a magnetic drive and incubated for 2 days at $37^{\circ} \mathrm{C}$ in a humidified atmosphere containing $5 \% \mathrm{CO}_{2}$. Then the fresh medium containing 20 or $50 \mu \mathrm{M}$ of tested compound was added to the wells. The spheroids were captured every two days using the Olympus IX73 inverted microscope (OLYMPUS CORPORATION). The quantitative analysis of compound anticancer activity in spheroids was performed using ImageJ (National Institutes of Health) and Microsoft Office Excel software).

\subsubsection{Antioxidant Activity}

The FRAP (ferric reducing antioxidant power) assay is based on the reduction of the colorless $\mathrm{Fe}^{3+}-2,4,6$-tripyridyl-s-triazine complex to the intensely blue $\mathrm{Fe}^{2+}-2,4,6$-tripyridyl$s$-triazine complex in acidic medium. FRAP values are calculated from increasing absorbances measured at $593 \mathrm{~nm}$. The FRAP reagent contained $2.5 \mathrm{~mL}$ of a $10 \mathrm{mM}$ TPTZ (2,4,6-tripyridyl-s-triazine) solution in $40 \mathrm{mM} \mathrm{HCl}$, along with $2.5 \mathrm{~mL}$ of $\mathrm{FeCl}_{3}(20 \mathrm{mM})$ and $25 \mathrm{~mL}$ of acetate buffer $(0.3 \mathrm{M}, \mathrm{pH}=3.6)$. For each compound, $100 \mu \mathrm{L}$ of it $(20 \mathrm{mM})$ was mixed with $3 \mathrm{~mL}$ of the FRAP reagent. The absorbance of the reaction mixture at $593 \mathrm{~nm}$ was measured spectrophotometrically. For comprising the calibration curve, five concentrations of $\mathrm{FeSO}_{4} \cdot 7 \mathrm{H}_{2} \mathrm{O}(5,10,15,20$, and $25 \mu \mathrm{M})$ were used, and the absorbances of the samples' solutions were then measured [92]. Each experiment was conducted in triplicate.

\subsubsection{Statistical Analysis}

All biological experiments were repeated at least three times. The mean and standard deviation are reported. The data were processes using Microsoft Office Excel 2016 software (Microsoft Corporation, Redmond, WA, USA). Statistical analysis was performed by using Student's t-tests. The level of significance was set as $p<0.05$.

\section{Conclusions}

In conclusion, a series of novel hydrazone-isatin derivatives were synthesized and evaluated for their anticancer and antioxidant properties. In the anticancer activity assay, the colon adenocarcinoma HT-29 cell line appeared to be more sensitive to the treatment with the hydrazone-isatin derivatives, compared to the malignant melanoma A375 cell line. Bis(hydrazone-isatins) were found to be more active than their mono analogues. $\operatorname{Bis}\left(N^{\prime}-\right.$ (2-oxoindolin-3-ylidene)propanehydrazide) 20, bearing the electron-donating methoxy group at the $p$-position of the benzene ring, and diphenylmethane derivative 35 , bearing two 5-oxo- $N^{\prime}$-(2-oxoindolin-3-ylidene)pyrrolidine-3-carbohydrazide "arms" at $p$-positions of the benzene rings, were the most active among all compounds synthesized. These compounds reduced the colony-forming abilities of both cell lines, and also inhibited the growth and viability of colon cancer and melanoma spheroids. 
The same bis(hydrazone-isatins) possessed the highest ferric reducing antioxidant power. These promising results suggest that variously substituted bis(hydrazone-isatins) based on an $\mathrm{N}$-substituted $\beta$-amino acid scaffold could be developed further as a new class of anticancer agents against aggressive malignant melanoma and colon adenocarcinoma tumors.

Supplementary Materials: The following are available online at https://www.mdpi.com/article/ 10.3390/ijms22157799/s1. Figures S1-S168 display ${ }^{1} \mathrm{H}$ NMR, ${ }^{13} \mathrm{C}$ NMR, and HRMS spectra of compounds 12-22, 26-28, 30, and 32-39.

Author Contributions: Conceptualization, I.T., K.K. and V.P.; methodology, I.T., I.J. and V.P.; formal analysis, I.T., I.J., K.K. and V.P.,; investigation, I.T., I.J. and V.P.; writing-original draft preparation, I.T., I.J., K.K. and V.P.; writing —review and editing, K.K. and V.P.; review and editing-final review, K.K., V.M. and V.P. All authors have read and agreed to the published version of the manuscript.

Funding: This research received no external funding.

Institutional Review Board Statement: Not applicable.

Informed Consent Statement: Not applicable.

Data Availability Statement: All datasets generated for this study are included in the article.

Conflicts of Interest: The authors declare no conflict of interest.

\section{References}

1. Siegel, R.L.; Miller, K.D.; Jemal, A. Cancer Statistics, 2019. CA Cancer J. Clin. 2019, 69, 7-34. [CrossRef]

2. Cheung-Ong, K.; Giaever, G.; Nislow, C. DNA-Damaging Agents in Cancer Chemotherapy: Serendipity and Chemical Biology. Chem. Biol. 2013, 20, 648-659. [CrossRef] [PubMed]

3. Farber, S.; Diamond, L.K. Temporary Remissions in Acute Leukemia in Children Produced by Folic Acid Antagonist, 4Aminopteroyl-Glutamic Acid. N. Engl. J. Med. 1948, 238, 787-793. [CrossRef]

4. Nitiss, J.L. Targeting DNA Topoisomerase II in Cancer Chemotherapy. Nat. Rev. Cancer 2009, 9, 338-350. [CrossRef] [PubMed]

5. Spivak, A.Y.; Nedopekina, D.A.; Gubaidullin, R.R.; Dubinin, M.V.; Belosludtsev, K.N. Conjugation of Natural Triterpenic Acids with Delocalized Lipophilic Cations: Selective Targeting Cancer Cell Mitochondria. J. Pers. Med. 2021, 11, 470. [CrossRef]

6. Baudino, T.A. Targeted Cancer Therapy: The Next Generation of Cancer Treatment. Curr. Drug Discov. Technol. 2015, 12, 3-20. [CrossRef] [PubMed]

7. Fabbro, D.; Ruetz, S.; Buchdunger, E.; Cowan-Jacob, S.W.; Fendrich, G.; Liebetanz, J.; Mestan, J.; O’Reilly, T.; Traxler, P.; Chaudhuri, B.; et al. Protein Kinases as Targets for Anticancer Agents: From Inhibitors to Useful Drugs. Pharmacol. Ther. 2002, 93, 79-98. [CrossRef]

8. Santos, R.; Ursu, O.; Gaulton, A.; Bento, A.P.; Donadi, R.S.; Bologa, C.G.; Karlsson, A.; Al-Lazikani, B.; Hersey, A.; Oprea, T.I.; et al. A Comprehensive Map of Molecular Drug Targets. Nat. Rev. Drug Discov. 2017, 16, 19-34. [CrossRef] [PubMed]

9. Liang, X.; Yang, Q.; Wu, P.; He, C.; Yin, L.; Xu, F.; Yin, Z.; Yue, G.; Zou, Y.; Li, L.; et al. The Synthesis Review of the Approved Tyrosine Kinase Inhibitors for Anticancer Therapy in 2015-2020. Bioorg. Chem. 2021, 113, 105011. [CrossRef] [PubMed]

10. Pandeya, S.N.; Smitha, S.; Jyoti, M.; Sridhar, S.K. Biological Activities of Isatin and Its Derivatives. Acta Pharm. 2005, 55, 27-46. [PubMed]

11. Leañez, J.; Nuñez, J.; García-Marchan, Y.; Sojo, F.; Arvelo, F.; Rodriguez, D.; Buscema, I.; Alvarez-Aular, A.; Bello Forero, J.S.; Kouznetsov, V.V.; et al. Anti-Leishmanial Effect of Spiro Dihydroquinoline-Oxindoles on Volume Regulation Decrease and Sterol Biosynthesis of Leishmania Braziliensis. Exp. Parasitol. 2019, 198, 31-38. [CrossRef]

12. Kumari, G.; Nutan; Modi, M.; Gupta, S.K.; Singh, R.K. Rhodium(II) Acetate-Catalyzed Stereoselective Synthesis, SAR and Anti-HIV Activity of Novel Oxindoles Bearing Cyclopropane Ring. Eur. J. Med. Chem. 2011, 46, 1181-1188. [CrossRef] [PubMed]

13. Kiran, G.; Maneshwar, T.; Rajeshwar, Y.; Sarangapani, M. Microwave-Assisted Synthesis, Characterization, Antimicrobial and Antioxidant Activity of Some New Isatin Derivatives. J. Chem. 2012, 2013, e192039. [CrossRef]

14. Christodoulou, M.S.; Nicoletti, F.; Mangano, K.; Chiacchio, M.A.; Facchetti, G.; Rimoldi, I.; Beccalli, E.M.; Giofrè, S. Novel 3,3-Disubstituted Oxindole Derivatives. Synthesis and Evaluation of the Anti-Proliferative Activity. Bioorg. Med. Chem. Lett. 2020, 30, 126845. [CrossRef] [PubMed]

15. de Paiva, R.E.F.; Vieira, E.G.; da Silva, D.R.; Wegermann, C.A.; Costa Ferreira, A.M. Anticancer Compounds Based on IsatinDerivatives: Strategies to Ameliorate Selectivity and Efficiency. Front. Mol. Biosci. 2020, 7, 627272. [CrossRef] [PubMed]

16. Kaur, M.; Singh, M.; Chadha, N.; Silakari, O. Oxindole: A Chemical Prism Carrying Plethora of Therapeutic Benefits. Eur. J. Med. Chem. 2016, 123, 858-894. [CrossRef] [PubMed]

17. Rizzo, M.; Porta, C. Sunitinib in the Treatment of Renal Cell Carcinoma: An Update on Recent Evidence. Ther. Adv. Urol. 2017, 9, 195-207. [CrossRef] [PubMed]

18. Chow, L.Q.M.; Eckhardt, S.G. Sunitinib: From Rational Design to Clinical Efficacy. JCO 2007, 25, 884-896. [CrossRef] 
19. London, C.A. Kinase Dysfunction and Kinase Inhibitors. Vet. Dermatol. 2013, 24, 181-187.e39-40. [CrossRef]

20. Roth, G.J.; Binder, R.; Colbatzky, F.; Dallinger, C.; Schlenker-Herceg, R.; Hilberg, F.; Wollin, S.-L.; Kaiser, R. Nintedanib: From Discovery to the Clinic. J. Med. Chem. 2015, 58, 1053-1063. [CrossRef]

21. Jia, Y.; Wen, X.; Gong, Y.; Wang, X. Current Scenario of Indole Derivatives with Potential Anti-Drug-Resistant Cancer Activity. Eur. J. Med. Chem. 2020, 200, 112359. [CrossRef] [PubMed]

22. Avendaño, C.; Menéndez, J.C. Chapter 9-Drugs That Inhibit Signalling Pathways for Tumor Cell Growth and Proliferation. In Medicinal Chemistry of Anticancer Drugs; Avendaño, C., Menéndez, J.C., Eds.; Elsevier: Amsterdam, The Netherlands, 2008; pp. 251-305. ISBN 978-0-444-52824-7.

23. Kudo, M.; Cheng, A.-L.; Park, J.-W.; Park, J.H.; Liang, P.-C.; Hidaka, H.; Izumi, N.; Heo, J.; Lee, Y.J.; Sheen, I.-S.; et al. Orantinib versus Placebo Combined with Transcatheter Arterial Chemoembolisation in Patients with Unresectable Hepatocellular Carcinoma (ORIENTAL): A Randomised, Double-Blind, Placebo-Controlled, Multicentre, Phase 3 Study. Lancet Gastroenterol. Hepatol. 2018, 3, 37-46. [CrossRef]

24. Wang, J.; Yun, D.; Yao, J.; Fu, W.; Huang, F.; Chen, L.; Wei, T.; Yu, C.; Xu, H.; Zhou, X.; et al. Design, Synthesis and QSAR Study of Novel Isatin Analogues Inspired Michael Acceptor as Potential Anticancer Compounds. Eur. J. Med. Chem. 2018, 144, 493-503. [CrossRef]

25. Kostova, I.; Saso, L. Advances in Research of Schiff-Base Metal Complexes as Potent Antioxidants. Curr. Med. Chem. 2013, 20, 4609-4632. [CrossRef] [PubMed]

26. Rollas, S.; Küçükgüzel, S.G. Biological Activities of Hydrazone Derivatives. Molecules 2007, 12, 1910-1939. [CrossRef]

27. Demurtas, M.; Baldisserotto, A.; Lampronti, I.; Moi, D.; Balboni, G.; Pacifico, S.; Vertuani, S.; Manfredini, S.; Onnis, V. Indole Derivatives as Multifunctional Drugs: Synthesis and Evaluation of Antioxidant, Photoprotective and Antiproliferative Activity of Indole Hydrazones. Bioorg. Chem. 2019, 85, 568-576. [CrossRef]

28. de Oliveira Carneiro Brum, J.; Tanos, C.C.F.; Steven, R.L.; José, D.F.V. Synthesis and Biological Activity of Hydrazones and Derivatives: A Review. Mini Rev. Med. Chem. 2020, 20, 342-368. [CrossRef]

29. Al-Salem, H.S.; Arifuzzaman, M.; Alkahtani, H.M.; Abdalla, A.N.; Issa, I.S.; Alqathama, A.; Albalawi, F.S.; Rahman, A.F.M.M. A Series of Isatin-Hydrazones with Cytotoxic Activity and CDK2 Kinase Inhibitory Activity: A Potential Type II ATP Competitive Inhibitor. Molecules 2020, 25, 4400. [CrossRef]

30. Ibrahim, H.S.; Abou-Seri, S.M.; Ismail, N.S.M.; Elaasser, M.M.; Aly, M.H.; Abdel-Aziz, H.A. Bis-Isatin Hydrazones with Novel Linkers: Synthesis and Biological Evaluation as Cytotoxic Agents. Eur. J. Med. Chem. 2016, 108, 415-422. [CrossRef]

31. Thangam, R.; Suresh, V.; Rajkumar, M.; Vincent, J.D.; Gunasekaran, P.; Anbazhagan, C.; Kaveri, K.; Kannan, S. Antioxidant and In Vitro Anticancer Effect of 2-Pyrrolidinone Rich Fraction of Brassica Oleracea Var. Capitata through Induction of Apoptosis in Human Cancer Cells. Phytother. Res. 2013, 27, 1664-1670. [CrossRef]

32. Dascalu, A.-E.; Ghinet, A.; Lipka, E.; Furman, C.; Rigo, B.; Fayeulle, A.; Billamboz, M. Design, Synthesis and Evaluation of Hydrazine and Acyl Hydrazone Derivatives of 5-Pyrrolidin-2-one as Antifungal Agents. Bioorg. Med. Chem. Lett. 2020, $30,127220$. [CrossRef]

33. Liu, S.-J.; Zhao, Q.; Peng, C.; Mao, Q.; Wu, F.; Zhang, F.-H.; Feng, Q.-S.; He, G.; Han, B. Design, Synthesis, and Biological Evaluation of Nitroisoxazole-Containing Spiro[Pyrrolidin-Oxindole] Derivatives as Novel Glutathione Peroxidase 4/Mouse Double Minute 2 Dual Inhibitors That Inhibit Breast Adenocarcinoma Cell Proliferation. Eur. J. Med. Chem. 2021, $217,113359$. [CrossRef] [PubMed]

34. Tumosienè, I.; Peleckis, A.; Jonuškienė, I.; Vaickelionienė, R.; Kantminienė, K.; Šiugždaitė, J.; Beresnevičius, Z.J.; Mickevičius, V. Synthesis of Novel 1,2- and 2-Substituted Benzimidazoles with High Antibacterial and Antioxidant Activity. Monatsh. Chem. 2018, 149, 577-594. [CrossRef]

35. Tumosienè, I.; Kantminienè, K.; Klevinskas, A.; Petrikaitè, V.; Jonuškienè, I.; Mickevičius, V. Antioxidant and Anticancer Activity of Novel Derivatives of 3-[(4-Methoxyphenyl)amino]propane-Hydrazide. Molecules 2020, 25, 2980. [CrossRef] [PubMed]

36. Meleddu, R.; Petrikaite, V.; Distinto, S.; Arridu, A.; Angius, R.; Serusi, L.; Škarnulytè, L.; Endriulaitytè, U.; Paškevičiutè, M.; Cottiglia, F.; et al. Investigating the Anticancer Activity of Isatin/Dihydropyrazole Hybrids. ACS Med. Chem. Lett. 2019, 10, 571-576. [CrossRef] [PubMed]

37. El Khoury, F.; Corcos, L.; Durand, S.; Simon, B.; Le Jossic-Corcos, C. Acquisition of Anticancer Drug Resistance Is Partially Associated with Cancer Stemness in Human Colon Cancer Cells. Int. J. Oncol. 2016, 49, 2558-2568. [CrossRef] [PubMed]

38. Rossi, S.; Cordella, M.; Tabolacci, C.; Nassa, G.; D’Arcangelo, D.; Senatore, C.; Pagnotto, P.; Magliozzi, R.; Salvati, A.; Weisz, A.; et al. TNF-Alpha and Metalloproteases as Key Players in Melanoma Cells Aggressiveness. J. Exp. Clin. Cancer Res. $2018,37$. [CrossRef]

39. Ross, K.C.; Chin, K.F.; Kim, D.; Marion, C.D.; Yen, T.J.; Bhattacharjee, V. Methotrexate Sensitizes Drug-Resistant Metastatic Melanoma Cells to BRAF V600E Inhibitors Dabrafenib and Encorafenib. Oncotarget 2018, 9, 13324-13336. [CrossRef]

40. Kopetz, S.; Lesslie, D.P.; Dallas, N.A.; Park, S.I.; Johnson, M.; Parikh, N.U.; Kim, M.P.; Abbruzzese, J.L.; Ellis, L.M.; Chandra, J.; et al. Synergistic Activity of the Src Family Kinase Inhibitor Dasatinib and Oxaliplatin in Colon Carcinoma Cells Is Mediated by Oxidative Stress. Cancer Res. 2009, 69, 3842-3849. [CrossRef]

41. Nunes, A.S.; Barros, A.S.; Costa, E.C.; Moreira, A.F.; Correia, I.J. 3D Tumor Spheroids as In Vitro Models to Mimic In Vivo Human Solid Tumors Resistance to Therapeutic Drugs. Biotechnol. Bioeng. 2019, 116, 206-226. [CrossRef] 
42. Parašotas, I.; Urbonavičiūtė, E.; Anusevičius, K.; Tumosienė, I.; Jonuškienė, I.; Kantminienė, K.; Vaickelionienė, R.; Mickevičius, V. Synthesis and Biological Evaluation of Novel Di- and Trisubstituted Thiazole Derivatives. Heterocycles 2017, 94, 1074. [CrossRef]

43. Tisovský, P.; Csicsai, K.; Donovalová, J.; Šandrik, R.; Sokolík, R.; Gáplovský, A. Effect of a =X-NH-Fragment, (X= C, N), on Z/E Isomerization and ON/OFF Functionality of Isatin Arylhydrazones, ((Arylamino)methylene)indolin-2-ones and Their Anions. Molecules 2020, 25, 3082. [CrossRef]

44. Pal, A.; Curtin, J.F.; Kinsella, G.K. In Silico and In Vitro Screening for Potential Anticancer Candidates Targeting GPR120. Bioorg. Med. Chem. Lett. 2021, 31, 127672. [CrossRef]

45. Abebe, F.A.; Hopkins, M.D.; Vodnala, S.N.; Sheaff, R.J.; Lamar, A.A. Development of a Rapid In Vitro Screening Assay Using Metabolic Inhibitors to Detect Highly Selective Anticancer Agents. ACS Omega 2021. [CrossRef]

46. Kachaeva, M.V.; Pilyo, S.G.; Zhirnov, V.V.; Brovarets, V.S. Synthesis, Characterization, and In Vitro Anticancer Evaluation of 2-Substituted 5-Arylsulfonyl-1,3-oxazole-4-carbonitriles. Med. Chem. Res. 2019, 28, 71-80. [CrossRef]

47. Danihelová, M.; Veverka, M.; Šturdík, E.; Jantová, S. Antioxidant Action and Cytotoxicity on HeLa and NIH-3T3 Cells of New Quercetin Derivatives. Interdiscip. Toxicol. 2013, 6, 209-216. [CrossRef]

48. Helmbach, H.; Rossmann, E.; Kern, M.A.; Schadendorf, D. Drug-Resistance in Human Melanoma. Int. J. Cancer 2001, 93, 617-622. [CrossRef]

49. Schumacher, U.; Nehmann, N.; Adam, E.; Mukthar, D.; Slotki, I.N.; Horny, H.-P.; Flens, M.J.; Schlegelberger, B.; Steinemann, D. MDR-1-Overexpression in HT 29 Colon Cancer Cells Grown in SCID Mice. Acta Histochem. 2012, 114, 594-602. [CrossRef] [PubMed]

50. Bedia, C.; Casas, J.; Andrieu-Abadie, N.; Fabriàs, G.; Levade, T. Acid Ceramidase Expression Modulates the Sensitivity of A375 Melanoma Cells to Dacarbazine. J. Biol. Chem. 2011, 286, 28200-28209. [CrossRef] [PubMed]

51. Margue, C.; Philippidou, D.; Kozar, I.; Cesi, G.; Felten, P.; Kulms, D.; Letellier, E.; Haan, C.; Kreis, S. Kinase Inhibitor Library Screening Identifies Synergistic Drug Combinations Effective in Sensitive and Resistant Melanoma Cells. J. Exp. Clin. Cancer Res. 2019, 38, 56. [CrossRef] [PubMed]

52. Tawfik, E.; Ahamed, M.; Almalik, A.; Alfaqeeh, M.; Alshamsan, A. Prolonged Exposure of Colon Cancer Cells to 5-Fluorouracil Nanoparticles Improves Its Anticancer Activity. Saudi Pharm. J. 2017, 25, 206-213. [CrossRef] [PubMed]

53. Napolitano, S.; Martini, G.; Rinaldi, B.; Martinelli, E.; Donniacuo, M.; Berrino, L.; Vitagliano, D.; Morgillo, F.; Barra, G.; De Palma, R.; et al. Primary and Acquired Resistance of Colorectal Cancer to Anti-EGFR Monoclonal Antibody Can Be Overcome by Combined Treatment of Regorafenib with Cetuximab. Clin. Cancer Res. 2015, 21, 2975-2983. [CrossRef]

54. Li, C.; Han, X. Co-Delivery of Dacarbazine and All-Trans Retinoic Acid (ATRA) Using Lipid Nanoformulations for Synergistic Antitumor Efficacy Against Malignant Melanoma. Nanoscale Res. Lett 2020, 15. [CrossRef] [PubMed]

55. Sinik, L.; Minson, K.A.; Tentler, J.J.; Carrico, J.; Bagby, S.M.; Robinson, W.A.; Kami, R.; Burstyn-Cohen, T.; Eckhardt, S.G.; Wang, X.; et al. Inhibition of MERTK Promotes Suppression of Tumor Growth in BRAF Mutant and BRAF Wild-Type Melanoma. Mol. Cancer Ther. 2019, 18, 278-288. [CrossRef]

56. Lee, S.-H.; Hong, J.H.; Park, H.K.; Park, J.S.; Kim, B.-K.; Lee, J.-Y.; Jeong, J.Y.; Yoon, G.S.; Inoue, M.; Choi, G.-S.; et al. Colorectal Cancer-Derived Tumor Spheroids Retain the Characteristics of Original Tumors. Cancer Lett. 2015, 367, 34-42. [CrossRef] [PubMed]

57. Zanoni, M.; Piccinini, F.; Arienti, C.; Zamagni, A.; Santi, S.; Polico, R.; Bevilacqua, A.; Tesei, A. 3D Tumor Spheroid Models for In Vitro Therapeutic Screening: A Systematic Approach to Enhance the Biological Relevance of Data Obtained. Sci. Rep. 2016, 6. [CrossRef] [PubMed]

58. Golas, J.M.; Lucas, J.; Etienne, C.; Golas, J.; Discafani, C.; Sridharan, L.; Boghaert, E.; Arndt, K.; Ye, F.; Boschelli, D.H.; et al. SKI-606, a Src/Abl Inhibitor with in Vivo Activity in Colon Tumor Xenograft Models. Cancer Res. 2005, 65, 5358-5364. [CrossRef]

59. Folkesson, E.; Niederdorfer, B.; Nakstad, V.T.; Thommesen, L.; Klinkenberg, G.; Lægreid, A.; Flobak, Å. High-Throughput Screening Reveals Higher Synergistic Effect of MEK Inhibitor Combinations in Colon Cancer Spheroids. Sci. Rep. 2020, 10, 11574. [CrossRef]

60. Vultur, A.; Villanueva, J.; Krepler, C.; Rajan, G.; Chen, Q.; Xiao, M.; Li, L.; Gimotty, P.A.; Wilson, M.; Hayden, J.; et al. MEK Inhibition Affects STAT3 Signaling and Invasion in Human Melanoma Cell Lines. Oncogene 2014, 33, 1850-1861. [CrossRef]

61. Yingchoncharoen, P.; Kalinowski, D.S.; Richardson, D.R. Lipid-Based Drug Delivery Systems in Cancer Therapy: What Is Available and What Is Yet to Come. Pharmacol. Rev. 2016, 68, 701-787. [CrossRef] [PubMed]

62. Jaracz, S.; Chen, J.; Kuznetsova, L.V.; Ojima, I. Recent Advances in Tumor-Targeting Anticancer Drug Conjugates. Bioorg. Med. Chem. 2005, 13, 5043-5054. [CrossRef] [PubMed]

63. Valko, M.; Leibfritz, D.; Moncol, J.; Cronin, M.T.D.; Mazur, M.; Telser, J. Free Radicals and Antioxidants in Normal Physiological Functions and Human Disease. Int. J. Biochem. Cell Biol. 2007, 39, 44-84. [CrossRef]

64. Halliwell, B. Free Radicals and Antioxidants: A Personal View. Nutr. Rev. 1994, 52, 253-265. [CrossRef] [PubMed]

65. Halliwell, B. Antioxidants in Human Health and Disease. Annu. Rev. Nutr. 1996, 16, 33-50. [CrossRef] [PubMed]

66. Pham-Huy, L.A.; He, H.; Pham-Huy, C. Free Radicals, Antioxidants in Disease and Health. Int. J. Biomed. Sci. 2008, 4, 89-96.

67. Valko, M.; Rhodes, C.J.; Moncol, J.; Izakovic, M.; Mazur, M. Free Radicals, Metals and Antioxidants in Oxidative Stress-Induced Cancer. Chem. Biol. Interact. 2006, 160, 1-40. [CrossRef]

68. Dastmalchi, N.; Baradaran, B.; Latifi-Navid, S.; Safaralizadeh, R.; Khojasteh, S.M.B.; Amini, M.; Roshani, E.; Lotfinejad, P. Antioxidants with Two Faces toward Cancer. Life Sci. 2020, 258, 118186. [CrossRef] 
69. Riazimontazer, E.; Sadeghpour, H.; Nadri, H.; Sakhteman, A.; Küçükkılınç, T.T.; Miri, R.; Edraki, N. Design, Synthesis and Biological Activity of Novel Tacrine-Isatin Schiff Base Hybrid Derivatives. Bioorg. Chem. 2019, 89, 103006. [CrossRef]

70. Çavuş, M.S.; Yakan, H.; Muğlu, H.; Bakır, T. Novel Carbohydrazones Including 5-Substituted Isatin: Synthesis, Characterization, and Quantum-Chemical Studies on the Relationship between Electronic and Antioxidant Properties. J. Phys. Chem. Solids 2020, 140, 109362. [CrossRef]

71. Strlic, M.; Radovic, T.; Kolar, J.; Pihlar, B. Anti- and Prooxidative Properties of Gallic Acid in Fenton-Type Systems. J. Agric. Food Chem. 2002, 50, 6313-6317. [CrossRef]

72. Calis, I.; Hosny, M.; Khalifa, T.; Nishibe, S. Secoiridoids from Fraxinus Angustifolia. Phytochemistry 1993, 33, 1453-1456. [CrossRef]

73. Saundane, A.R.; Katkar, V.T.; Vaijinath, A.V. Synthesis, Antimicrobial, and Antioxidant Activities of $N-\left[\left(5^{\prime}\right.\right.$-Substituted-2'-phenyl1H-indol-3'-yl)methylene]-5H-dibenzo[b,f]azepine-5-carbohydrazide Derivatives. J. Chem. 2013, 2013, e530135. [CrossRef]

74. Sugihara, T.; Rao, G.; Hebbel, R.P. Diphenylamine: An Unusual Antioxidant. Free Radic. Biol. Med. 1993, 14, 381-387. [CrossRef]

75. Tumosiene, I.; Kantminiene, K.; Pavilonis, A.; Mazeliene, Z.; Beresnevicius, Z.J. Synthesis of Azole Derivatives from 3Phenylaminopropanhydrazide and Evaluation of Their Antimicrobial Efficacy. Heterocycles 2009, 78, 59-70. [CrossRef]

76. Solomko, Z.F.; Malinovskii, M.S.; Braichenko, V.T. Investigations in the Field of N-Aryl- $\beta$-amino Acids: V. Hydrazides of $N$-Aryl- $\beta$-alanines. Pharm. Chem. J. 1971, 5, 664-666. [CrossRef]

77. Tumosienè, I.; Jonuškienè, I.; Kantminienè, K.; Beresnevičius, Z.J. The Synthesis of Azole Derivatives from 3-[(4-Methylphenyl)amino]propa and Its $N^{\prime}$-Phenylcarbamoyl Derivatives, and Their Antibacterial Activity. Monatsh. Chem. 2012, 143, 1441-1450. [CrossRef]

78. Baltrusis, R.; Marijosius, J. Synthesis of 1-Aryldihydrouracils and 1-Aryl-2-thiodihydrouracils and Their Transformations. Khim. Geterotsikl. Soedin. 1969, 5, 904-907.

79. Gilani, S.; Khan, S.; Alam, O.; Kumar, H. Synthesis and Biological Evaluation of Some Substituted-1,2,3-triazole Derivatives. Indian J. Heterocycl. Chem. 2008, 17, 245-248.

80. Saeed, A.; Hussain, S.; Abbas, N.; Bolte, M. Synthesis, Characterization and Crystal Structure of Some Novel 1-(3,5-Dimethyl-1Hpyrazol-1-yl)-3-(substituted anilino)propan-1-ones. Chin. J. Chem. 2009, 27, 1141-1147. [CrossRef]

81. Tumosiene, I.; Jakiene, E.; Beresnevicius, Z.J.; Mikulskiene, G. Synthesis and Properties of Dihydrazides of N-Phenyl-and $N$-(4-Methylphenyl)- $N$-carboxyethyl- $\beta$-alanines. Cheminé Technologija 2006, 3, 58-64.

82. Tumosienè, I.; Beresnevičius, Z.J.; Kantminienė, K.; Mikulskienė, G. Synthesis of 3-\{[2-( $N^{1}$-alkylidenehydrazinocarbonyl)ethyl](4alkoxyphenyl)amino\}propanohydrazide Derivatives and Analysis of Their Isomer Composition. Chemija 2008, 19 , 44-51.

83. Anusevicius, K.; Vaickelioniene, R.; Mickevicius, V.; Mikulskiene, G. Synthesis of Bis Azole, Diazole, and Triazole Derivatives from $N$-(4-Chloro/Iodophenyl)- $N$-carboxyethyl- $\beta$-alanine Dihydrazides. J. Heterocycl. Chem. 2013, 50, 309-314. [CrossRef]

84. Brokaite, K.; Mickevicius, V.; Mikulskiene, G. Synthesis and Investigation of Some 1,4-Disubstituted 2-Pyrrolidinones. Chem. Heterocycl. Compd. 2006, 42, 1158-1167. [CrossRef]

85. Mickevičius, V.; Vaickelionienè, R.; Sapijanskaitè, B. Synthesis of Substituted 1,3,4-Oxadiazole Derivatives. Chem. Heterocycl. Comp. 2009, 45, 215-218. [CrossRef]

86. Paytash, P.L.; Sparrow, E.; Gathe, J.C. The Reaction of Itaconic Acid with Primary Amines. J. Am. Chem. Soc. 1950, 72, 1415-1416. [CrossRef]

87. Mickevičius, M.; Beresnevičius, Z.J.; Mickevičius, V. Synthesis and properties of 1-Aryl-4-(hydrazinocarbonyl)-2-pyrrolidinones. Chemine Technologija 2004, 2, 68-74.

88. Hirai, K.; Takeuchi, K.; Abe, M.; Ito, N. Latent Curing Agents for Epoxy Resins. U.S. Patent 4542202A, 17 September 1985.

89. Grigalius, I.; Petrikaite, V. Relationship between Antioxidant and Anticancer Activity of Trihydroxyflavones. Molecules 2017, 22, 2169. [CrossRef]

90. Bytautaite, M.; Petrikaite, V. Comparative Study of Lipophilic Statin Activity in 2D and 3D In Vitro Models of Human Breast Cancer Cell Lines MDA-MB-231 and MCF-7. OncoTargets Ther. 2020, 13, 13201-13209. [CrossRef] [PubMed]

91. Čeponytè, U.; Paškevičiūte, M.; Petrikaitè, V. Comparison of NSAIDs Activity in COX-2 Expressing and Non-Expressing 2D and 3D Pancreatic Cancer Cell Cultures. Cancer Manag. Res. 2018, 10, 1543-1551. [CrossRef] [PubMed]

92. Huang, D.; Ou, B.; Prior, R.L. The Chemistry behind Antioxidant Capacity Assays. J. Agric. Food Chem. 2005, 53, 1841-1856. [CrossRef] 